\title{
LA HORA DE LA TV: INCURSIÓN DE LA TELEVISIÓN Y LA TELENOVELA EN LA VIDA COTIDIANA DE LA CIUDAD DE MÉXICO $(1958-1966)^{*}$
}

\author{
Laura Camila Ramírez Bonilla \\ El Colegio de México
}

\section{INTRODUCCIÓN}

T a mujer se llamaba Nora. Venía de provincia. Aunque _carecía de instrucción, había conseguido un puesto de secretaria en una oficina de la ciudad. Confiaba en que su inteligencia y su simpatía fueran suficientes para llamar la atención de su jefe y mejorar su posición social. La joven no tardó en conseguir su propósito. Al poco tiempo, Nora estaba instalada en un departamento con todas las comodidades para ella y el señor de la casa, su jefe, señor de otra casa más y esposo de una abnegada mujer de clase alta.

Fecha de recepción: 9 de diciembre de 2013

Fecha de aceptación: 27 de enero de 2015

\footnotetext{
* La autora agradece de manera especial a la doctora Pilar Gonzalbo Aizpuru sus oportunos comentarios, recomendaciones e impulso para realizar este trabajo de investigación.
} 
La alteración abrupta de la rutina es el sino de la telenovela y su argumentación: ${ }^{1}$ el accidente, la transformación de un estado de cosas "normales" para un sector social, en un entorno cultural y un contexto histórico específicos. La telenovela juega, o bien con un "día a día" que de pronto se ve atravesado por el conflicto y la anomalía, o bien con circunstancias irregulares que en medio de su extrañeza asumen condiciones de cotidianidad. Su efectividad, hasta nuestros días, está en la habilidad de captar la excepción y el contratiempo en situaciones con las cuales el espectador se siente familiarizado y es capaz de reconocerse. El melodrama televisivo tiene la destreza de representar rupturas de las relaciones humanas - muchas de ellas incluso inverosímiles - con un obstinado sentimentalismo, con hincapié en la vida emocional y amorosa de los personajes involucrados y, en especial, con reflejos de los valores, estereotipos y preocupaciones morales de la sociedad.

${ }^{1}$ Siguiendo a Lizaur, en términos muy generales, la telenovela se puede entender como una historia narrada por episodios en televisión, con una tensión lineal creciente, que alcanza su clímax en el momento en que se resuelve el conflicto principal. Acompañada de subtramas, la historia recurre al esquema del melodrama para articular la narración. Ahora bien, como género televisivo, su antecedente más próximo fue la soap-opera estadounidense, que a diferencia de la telenovela está proyectada para tener una duración de años de emisión - las telenovelas están contempladas en un límite de episodios. En un ambiente como el de México, la telenovela como fenómeno de entretenimiento se explica también por la importante penetración que años atrás tuvieron los melodramas fílmicos nacionales y las radionovelas. El propósito de este texto no es ahondar en aspectos conceptuales del tema y la estructura narrativa del género. Esta definición únicamente tiene la función de familiarizar al lector con una descripción básica que permita diferenciar a la telenovela de otros géneros de la televisión. Véase Lizaur, "La telenovela mexicana", p. 110. 
Hablar de telenovela en México a finales de la década de 1950 es hablar de una novedad por partida doble. En un primer momento se refiere a la experiencia de lo nuevo, de lo no visto antes. El televisor, la televisión y la telenovela eran recién llegados. En agosto de 1950, después de varias pruebas, ${ }^{2}$ el primer canal comercial del país había iniciado labores siendo propiedad de la familia O'Farril. ${ }^{3}$ Inaugurando un sistema privado de televisión para México, el XHTVCanal 4 se presentó oficialmente al público con la lectura del IV Informe de Gobierno del presidente de la República, Miguel Alemán Valdés, el 1ํำ de septiembre de ese año. ${ }^{4}$ Lo nuevo llegaba con la concurrencia de actividades, tecnologías y productos de consumo inéditos en el país. Por eso, en un segundo momento, la sensación de novedad se experimentó desde el impacto que tuvieron los "recién llegados" en las rutinas de la gente. La incorporación del televisor, la televisión y la telenovela en las prácticas cotidianas del público fue un hecho que con el tiempo se convirtió en hábito. Se trataba de la incursión de un objeto tecnológico y de una experiencia de entretenimiento en el día a día de una

2 Desde la década de 1930, el ingeniero Guillermo González Camarena había experimentado con la televisión, logrando las primeras transmisiones no comerciales en sus estudios en el Distrito Federal.

${ }^{3}$ No obstante, la empresa ya había realizado su primera transmisión de prueba, el 27 de julio de ese año. El 31 de agosto, desde el Jockey Club, O’Farrill realizó una preinauguración de las emisiones oficiales que iniciarían a partir del $1^{\circ}$ de septiembre. Así lo relata el primer locutor que se presentó ante las cámaras en México, en 1950, Gonzalo Castellot. Castellot, La televisión en México, pp. 25-26.

4 "La televisión, el más nuevo adelanto, ya funciona en México", Novedades (1ํsep. 1950), p. 1; "Entusiasmó a México la televisión”, Novedades (2 sep. 1950), p. 1. 
sociedad acostumbrada a ver imágenes en movimiento en una sala de cine, no en la sala de su casa. Aquí la novedad es la modificación de horarios, espacios, gustos, prácticas, percepciones, mentalidades y modos de interacción. A partir de entonces, y en términos muy básicos, el televisor se convertiría en el electrodoméstico deseado, incluso símbolo de prestigio social; la televisión sería la industria de las comunicaciones y el espectáculo con más proyección de la segunda mitad del siglo xx y la telenovela se transformaría en un género con identidad y recursos propios, capaz de capturar la atención de un público neófito frente al medio, pero conocedor y expectante ante los intríngulis de los melodramas ya vistos y oídos en el cine y la radio. "Era impactante [...] mi papá nos había dicho que íbamos a poder ver en esa cajita a gente que estaba en otro lado. ¿Pero cómo?, decíamos nosotros. Éramos muy chicos, claro, pero era la primera impresión. ¿Cómo en esa cajita iba a caber la gente?”. 5

En su contexto de llegada, la televisión y la telenovela ofrecen dos experiencias paralelas, urbanas, características del crecimiento de la clase media y marcadas por la previa relación del auditorio con el cine y la radio. Por un lado, la imagen en movimiento unida al sonido, práctica dada por el cinematógrafo y sus avances tecnológicos, industria que además había visto cómo en la última década el melodrama capturaba la producción fílmica nacional y la atención de los espectadores. ${ }^{6} \mathrm{Y}$ por otro lado, lo construido por la radio y la radionovela, el primero como electrodoméstico de entre-

${ }^{5}$ Entrevista RMT. 15 de noviembre de 2012. Realizada por la autora.

${ }^{6}$ En los años cincuenta, el melodrama desplazó a otros géneros cinematográficos no solo en las producciones mexicanas, sino en países como Argentina y Cuba. Este último logró incluso coordinar esta preferencia 
tenimiento que podía entrar a la intimidad de la casa y la familia y ocupar un lugar en su cotidianidad, ${ }^{7}$ y el segundo, como género radiofónico exitoso, con producción permanente, profesionalizado, con públicos y horarios consolidados, integrado a la vida doméstica de muchos mexicanos. La televisión rápidamente encarnó el papel de “innovador”, pese a las referencias conocidas. Con transmisiones "en vivo y en directo”, desde la comodidad de la casa - el espacio por antonomasia de la familia -, el entretenimiento ya no sólo sería oído sino también visto. No sería necesario desplazarse al teatro o a la sala de cine, ni exponerse a los "peligros" de la calle para ver y oír espectáculos. El nuevo medio ofrecía una nueva experiencia, y en ella, la telenovela parecía ser una suerte de síntesis: era el melodrama fílmico y radial renovado, adaptado a la innovación tecnológica del momento y a las expectativas de un público ansioso con la "vida moderna".

El propósito de este trabajo es rastrear y analizar de qué manera la llegada de la televisión, y en particular, del género de la telenovela, a finales de la década de 1950, impactó en la vida cotidiana de los televidentes en la ciudad de México. Para este ejercicio se acudió a los contenidos de los primeros melodramas emitidos en México, su registro en prensa y revistas de la época y la experiencia de personas y familias

por el melodrama con la programación exitosa de radionovelas. R. GoNZÁlEZ, “Lágrimas de celuloide”, pp. 143-144.

7 La incursión de la radio en distintas cotidianidades de la ciudad de México, entre ellas el hogar, es tratada por Roberto Ornelas, quien comprueba que desde 1923 los aparatos receptores empezaron a popularizarse y a encontrar, poco a poco, un espacio de amplia recepción en el comercio y en las preferencias de la clase media posrevolucionaria. Ornelas, "Radio y cotidianidad en México", pp. 142-146. 
de clase media, entre 1958 y $1966,{ }^{8}$ que fueron entrevistadas y encuestadas a propósito del tema. Entenderemos la telenovela no sólo como uno de los productos televisivos más importantes de América Latina y el género de ficción audiovisual de mayor legitimidad y vitalidad entre el público de la región," sino como "un producto hecho especialmente para significar". ${ }^{10} \mathrm{La}$ telenovela es un dispositivo de sentidos.

Teniendo en cuenta que se puede considerar a la telenovela como el primer género genuinamente televisivo producido en México, con un concepto, contenido, producción y recursos artísticos y técnicos diseñados exclusivamente para la televisión, es posible cuestionarse si su incursión en la programación de 1958 a 1966 significó o no una modificación de los usos y las prácticas del "hombre ordinario". ${ }^{11}$ Para el caso del Distrito Federal, ¿la aparición del melodrama introdujo una nueva "cotidianidad" en los espectadores?, ¿cómo se reflejó esta "nueva cotidianidad" en los espacios, los tiempos, las rutinas, los gustos y los imaginarios de los televidentes?, ¿confluyeron la cotidianidad mostrada por el género televisivo y la cotidianidad vivida por la sociedad capitalina de finales de los cincuenta?

Para este fin, se recurrió a cuatro tipos de fuentes: primero, hemerografía del periodo estudiado: Excelsior,

${ }^{8}$ Esta demarcación temporal se definió a partir de los dos criterios: primero, los resultados de las encuestas y las entrevistas, sujetos a los recuerdos más vivos de las personas consultadas y sus experiencias; y segundo, porque el periodo representa una etapa de inicio y consolidación de la producción de telenovelas en el país, que para este periodo inicia con Senda Probibida (1958) y finaliza con El derecho de nacer (1966).

9 Como lo plantean Mazziotti, Telenovela, p. 25; Martín-Barbero, "La telenovela en Colombia”, p. 1, y J. A. González, La cofradía, p. 19.

${ }^{10} \mathrm{~J}$. A. González, La cofradía, p. 21. Las cursivas son mías.

11 De Certeau, La invención de lo cotidiano, pp. xxxix-lv. 
El Universal y Novedades (1958-1960) y las revistas TeleGuía (1957-1958, 1963-1966) y TV-54 (1954-1956), estas dos últimas, publicaciones especializadas en el medio. Segundo, se realizó una encuesta a 53 personas, entre los 55 y 85 años de edad, que vivieron en México D. F. durante el periodo objeto de estudio. El ejercicio debe considerarse parte de un trabajo piloto, exploratorio de la recepción de la televisión y la telenovela en una población específica. ${ }^{12}$ Servirá como referencia del contexto, de la diversidad de públicos, de distintas percepciones sobre el medio y el género, y de identificación de diferencias y semejanzas en gustos, experiencias, condiciones y hábitos; no obstante, sus resultados no pueden leerse como estadísticamente representativos de la población del Distrito Federal de la época, ni como un estudio acabado acerca de las preferencias sobre el medio y los melodramas. Tercero, se hicieron entrevistas no estructuradas a 5 personas ( 4 mujeres y 1 hombre), entre 64 y 85 años, que vivían en la ciudad de México durante el tiempo estudiado y recuerdan haber visto telenovelas en aquella época. Este ejercicio sirvió para contrastar resultados de las encuestas y complementar con detalles temas allí comprendidos. También se incluyeron 10 entrevistas realizadas por la revista TV Guia, entre octubre y diciembre de 1966, a 10 televidentes que dan su opinión sobre el género y la

12 La población se caracteriza por: ser estudiantes de la Universidad de la Tercera Edad, campus Mixcoac, Delegación Benito Juárez; 79\% son mujeres y $21 \%$ hombres; se definen como personas de clase media y tienen un grado de escolaridad entre secundaria y licenciatura. Debido al carácter tan específico de la población, no se busca generalizar a partir de sus respuestas, sino complementarlas y compararlas con los hallazgos aportados por las demás fuentes, pues su perfil influye en la percepción que ellos tienen de las telenovelas. 
televisión de la época. Esta última publicación constituye un material de primera mano como fuente de consulta, no solo porque permite una aproximación a los acontecimientos relacionados con la programación diaria, sino porque permite rastrear aspectos de la recepción: algunas reacciones de los públicos y sus posibles modos de ver televisión y telenovelas en la época. Igualmente, se acudió a entrevistas contenidas en libros y periódicos a directores, productores, actores y ejecutivos que estuvieron involucrados con la televisión durante el periodo. ${ }^{13} \mathrm{Y}$ cuarto, material audiovisual, extractos de algunas telenovelas, películas y documentales de la época, que hicieron referencia al tema investigado. ${ }^{14}$

Finalmente, el texto se encuentra dividido en cinco partes: primero, aspectos conceptuales y de contexto, desde los cuales se abordará el estudio de las telenovelas como dispositivos de sentido en la vida cotidiana del México de mediados de siglo; segundo, la llegada de la telenovela a la televisión mexicana; tercero, la incursión de la telenovela en el tiempo, los horarios y las rutinas de los televidentes; cuarto, la disposición del espacio en función de la telenovela:

${ }_{13}$ Los libros de Carrandi, Testimonio de la televisión mexicana, y de CASTEllot, Historia de la televisión, contienen entrevistas de este tipo. ${ }^{14}$ En cuanto al material audiovisual se hizo un seguimiento de la versión cinematográfica de El derecho de nacer (1952), Senda Probibida (1958), Gutierritos (1959), Teresa (1961) y Quinceañera (1960), las tres últimas dirigidas por el alemán Alfredo Crevenna. Igualmente se trabajó con extractos de las telenovelas Gutierritos (1965), El derecho de nacer (1966), María Isabel (1966) y Corazón Salvaje (1966), y de la versión de radionovela de Gutierritos (1955), emitida por la XEQ-México. No existe material de archivo audiovisual de las primeras telenovelas producidas en México, pues en esa época no se podían grabar las producciones. Solo hasta la llegada del video tape, en el cambio de década, fue posible dejar de realizar y de transmitir en vivo y en directo los melodramas televisivos. 
dónde, cómo y con quiénes se veía el melodrama televisivo; y quinto, una aproximación al televidente como sujeto que se empieza a familiarizar con el melodrama. Para terminar, el lector encontrará unas consideraciones finales que sugieren temáticas pendientes y futuras posibilidades de investigación en torno del tema.

\section{MÉXICO ESTABA CAMBIANDO}

Un partido de béisbol en el Parque Delta fue el acto que eligió Emilio Azcárraga Vidaurreta, empresario dueño de la XEW Radio, para inaugurar las trasmisiones del nuevo XEWTV-Canal 2, el 21 de marzo de 1951, en la ciudad de México. ${ }^{15}$ En mayo del año siguiente, Guillermo González Camarena, científico e inventor, responsable de las primeras transmisiones experimentales de televisión en México, inauguró el XHGC-Canal 5. Las dos nuevas estaciones se unían al Canal 4, de la familia O’Farril, que para 1951 había consolidado una parrilla de programación entre las $11 \mathrm{de}$ la mañana y la media noche. Sin embargo, la vida independiente de los tres canales no sería larga. Paralela a la apertura de estaciones en otras ciudades del país, los canales 2, 4 y 5 se fusionaron para crear oficialmente, el 25 de marzo de 1955, Telesistema Mexicano S. A., propiedad mayoritaria de Azcárraga Vidaurreta. ${ }^{16}$ El esquema no solo modificaba

15 Excelsior, "Beisbol en televisión" (20 mar. 1951). Castellot, La televisión en México, pp. 50-51.

${ }_{16}$ Antecedente de Televisa, fundada en 1972, empresa que contaría con la participación accionaria del expresidente Miguel Alemán Valdés. La relación cercana entre representantes de la clase política mexicana y Telesistema y Televisa facilitó una connivencia de favores mutuos y permitió 
la estructura de competencia que hasta entonces se había propiciado en México, sino que fundaba un modelo de primacía de la televisión privada, con carácter monopólico. El esquema privado se tomaba de la experiencia estadounidense, en contraste con una apuesta pública por la que optaron países como Inglaterra. ${ }^{17}$

Para entonces, México no era ajeno a la propagación de televisores en los hogares, aunque su número aún se consideraba incipiente en comparación con países desarrollados. En 1952, se calculaba que había unos 20000 aparatos en el país; ${ }^{18}$ la misma cifra se había calculado para la región londinense 13 años atrás. ${ }^{19} \mathrm{El}$ televisor, la gran innovación tecnológica del momento, ya había consolidado un mercado próspero en los países desarrollados. Para finales de la década, se calculaba la existencia de 87 millones de receptores, de los cuales $64 \%$ pertenecían a Estados Unidos..$^{20}$ Ahora bien,

incluso la rotación de personal de la televisión al sector público. OrOzco, Historia de la televisión en América Latina, pp. 208-209. RodRíGUez Kuri y González Mello, “El fracaso del éxito, 1970-1985”, p. 715.

${ }^{17}$ El gobierno de Miguel Alemán optó por un modelo privado y comercial, pese a las recomendaciones hechas por la Comisión de Televisión del Instituto Nacional de Bellas Artes (INBA), que conformó el mismo gobierno con el fin de estudiar qué sistema le sería más conveniente al país. En 1947, Alemán nombró a Salvador Novo para que liderara dicho estudio de factibilidad y analizara los casos de Estados Unidos, Inglaterra y Francia. El estudio concluyó que, con adaptaciones, el modelo más oportuno para México era público, como el adelantado por la BBC de Londres. Novo, Memorias mexicanas, pp. 10-11, 13-17.

${ }^{18}$ La cifra fue tomada de Fernández, "Fallas de origen", p. 53, quien a su vez hace la reseña del texto de Mejía BARQuerera, "Del canal 4 a Televisa”. ${ }_{19}$ Esta cifra fue tomada de Pierre y Tudesq, Historia de la radio y la televisión, p. 83.

20 Esta cifra fue tomada de Pierre y Tudesq, Historia de la radio y la televisión, p. 110. 
mientras en estos países el telerreceptor se popularizaba entre la clase media como "el electrodoméstico de moda", en México y América Latina era aún sinónimo de lujo de unos pocos. La precariedad de las cifras mexicanas muestra el rezago que había frente a industrias como la estadounidense. Las mediciones del rating y del crecimiento del mercado no son claras al finalizar los años cincuenta. En junio de 1958, el diario Excelsior publicó los resultados de un estudio que concluyó que en el D. F. existían 428824 televidentes. ${ }^{21}$ En investigación se habían visitado 326000 hogares, "tanto en las colonias de familias acomodadas, como en las de modestos recursos". Según sus cifras, cada televisor tenía un auditorio de 4.2 personas en promedio. ${ }^{22} \mathrm{El}$ desfase y la contradicción en los datos eran comunes. ${ }^{23} \mathrm{Ni}$ la prensa ni los empresarios determinaban aún con exactitud las dimensiones del fenómeno que estaban provocando el televisor y la televisión en su primera década.

Lo cierto era que México estaba cambiando. Con un poco más de 3200000 de habitantes en 1958, según el Anuario estadístico, ${ }^{24}$ el país estaba implementando en una intensa política de modernización ${ }^{25}$ y experimentando una creciente

${ }^{21}$ De una población de 4706736 habitantes (INEgi, Anuario estadístico, 1958-1959), es decir, según este estudio, aproximadamente 10.9\% de los citadinos veían televisión con frecuencia y se definían como televidentes. 22 "Hay 428.824 televidentes", Excelsior (12 jun. 1958).

23 El Universal señaló que en abril de 1958, 2000000 de televidentes habían visto los programas transmitidos por los canales capitalinos, cifra calculada por una de las agencias autorizadas para medir el rating en México. "Dos millones de televidentes”, El Universal (15 jun. 1958). ${ }^{24}$ El Anuario señala la cifra exacta de 32347698 habitantes para ese año. Véase INEGI, Anuario estadístico 1958-1959, p. 35.

${ }^{25}$ LoAezA, "Modernización autoritaria”, pp. 674-677. 
urbanización asimétrica que, para la década de 1950, concentraba $40 \%$ de los habitantes en ciudades como el Distrito Federal. ${ }^{26}$ En lo cotidiano, la revolución tecnológica posterior a la segunda guerra mundial popularizó el arribo de los electrodomésticos a los hogares. La misma sociedad urbana empezó a demandar el uso de estos utensilios, al tiempo que la publicidad, adaptando al consumidor a un american way of life, les hacía ver que "la salvación" estaba en la tecnología, como señala Álvaro Matute. ${ }^{27}$ Desde antes de su instalación, la televisión se vinculó al discurso del progreso y al afán modernizador que vivía México desde la segunda mitad de los años cuarenta. El medio encarnó la urgencia de estar a tono con los adelantos tecnológicos de los países desarrollados. El discurso parecía casi sublevar los efectos del recién llegado: marcará "páginas indelebles del progreso material de nuestro país”, señaló Novedades unos días después de su inauguración. ${ }^{28}$

En ese contexto, el cine, el teatro y la radio eran el centro del entretenimiento masivo. Estos medios ya habían recorrido una trayectoria propia, que les permitió, en especial al cine y a la radio, consolidarse en la primera mitad del siglo xx. En contraste, la televisión era un competidor principiante. Su particularidad, según Monsiváis, estaba en definir un lugar propio en el encuentro entre modernización y tradición: el adentro. Se trataba de un espacio "donde se congregan las seguridades, entre ellas y principalmente el

${ }^{26}$ Datos tomados de Rodríguez Kuri y González Mello, "El fracaso del éxito", p. 700.

${ }^{27}$ Matute, "De la tecnología al orden doméstico", pp. 157-158.

28 "La ceremonia del Grito será pasada en televisión", Novedades (15 sep. 1950). 
espectáculo de la familia unida en torno al aparato". En oposición al afuera, donde el placer por la vida en las calles era desplazado por "las multitudes y los peligros". La televisión fue una apuesta por el adentro, por lo doméstico, por el día a día dentro de la casa y la familia. Por esa razón, termina siendo "el gran interlocutor a quien se le cede el centro del diálogo familiar" ${ }^{29}$ Su fórmula parece contundente: una suerte de síntesis entre el cine, la radio y el teatro, los grandes medios de comunicación y entretenimiento de la época. La televisión ofrecía la posibilidad de tener imagen en movimiento, información, ficción y divertimento en el centro de la sala de la casa: esa fue su gran innovación.

El televisor no apareció como un artefacto personal, para uso individual. En términos de cultura material, para el periodo de estudio de esta investigación, la adquisición del televisor, y con él la acción de ver televisión y telenovelas, remitieron a un acto colectivo. La actividad y el aparato terminaron reflejándose en la cotidianidad familiar. El impacto del melodrama, entendido como producto hecho para significar, estuvo asociado a las rutinas domésticas, así como a los desempeños, las convenciones sociales, los modelos y los estereotipos creados alrededor de las familias de la época. Tanto en sus propios contenidos como en los procesos de recepción, la televisión y la telenovela estaban vinculadas a las estructuras familiares del momento, así como a los ideales de familia y al lugar de ésta y sus miembros en la sociedad. ${ }^{30}$ "Es objetivo y materia continua de lucha y rede-

${ }^{29}$ Monsivárs, “Lo entretenido y lo aburrido”, p. 214.

30 Como objeto frente al cual se reacciona aprobando o desaprobando, la telenovela puede ser una puerta de entrada al estudio de las estructuras familiares contemporáneas en América Latina y otras áreas del mundo. 
finición histórica de lo 'familiar' de un modo - precisamente - 'familiar' de ordenar, sentir, gozar y vivir el mundo."31 En otras palabras, televisión y telenovela continuaban el camino de idealización de la familia nuclear y reafirmación de la moral católica que habían promovido en su momento la radio mexicana ${ }^{32}$ y el melodrama cinematográfico. ${ }^{33}$

Podemos sostener que la telenovela es efectiva toda vez que se inserta en la cotidianidad del público, la representa y la reproduce. El televidente es capaz de reconocerse en varias de las situaciones que el melodrama presenta. Ese reconocimiento aparece en un doble sentido, según MartínBarbero: primero, desde el propio contenido de la telenovela, lo que "pone en juego el melodrama es precisamente el drama del reconocimiento. [...] lo que mueve la trama es siempre el desconocimiento de una identidad y la lucha contra los maleficios, las apariencias, contra todo lo que la oculta y disfraza". ${ }^{34}$ Y segundo, desde el ejercicio del televidente de acercarse y examinar algo en lo cual se puede ver reflejado, que le genera un mayor o menor grado de identificación. Como plantea Luhman, "hace surgir objetos reales autorreproducidos", son "objetos duplicados" que posibilitan el cruce de los límites entre lo real y lo ficticio. ${ }^{35}$ Ahora bien, las reacciones de los espectadores a esa identificación y reconocimiento son diversas. Las respuestas no son predecibles ni moldeables. "Lo que acontece en el interior del

31 J. A. González, La cofradía, p. 20.

32 Ornelas, "Radio y cotidianidad en México", p. 155.

33 Así lo evidencia el estudio de Julia Tuñón sobre el cine mexicano.

TuÑón, Mujeres de luz y sombra en el cine mexicano, pp. 19 y 74.

${ }^{34}$ Martín-Barbero, et. al., Televisión y melodrama, p. 27.

35 Luhman, La realidad, p. 77. 
espectador individual es al final de cuentas inobservable", 36 y no puede ser controlado cabalmente por los medios de comunicación de masas, ni definido con plena exactitud por la investigación académica. El dinamismo de los espectadores y su variada capacidad de respuesta, desde sus intereses, imaginarios y emociones, hace que el registro de la recepción siempre sea incompleto.

\section{LA LLEGADA DE LA TELENOVELA: ¿LOS NUEVOS MIEMBROS DE LA FAMILIA?}

"Las telenovelas fueron mucho después." ${ }^{37}$ En efecto, el lunes 9 de junio de 1958, a ocho años de la primera transmisión de televisión comercial en México, miles de televidentes le apostaron a un experimento: la "primera novela diaria en T.V.”. ${ }^{38}$ En el canal 4 de Telesistema, a las 6:30 p. m., Silvia Derbez inauguró el género con el personaje de Nora, una secretaria que seduce a su jefe casado. ${ }^{39}$ Senda Probibi$d a$, bajo la dirección de Rafael Banquells, fue lanzada por la prensa nacional como la novedad del momento. En tono de

${ }^{36}$ Luhman, La realidad, pp. 89-90.

37 Entrevista a ECM y HCM. 1ํ de noviembre de 2012. Realizada por la autora.

38 Así fue publicitada en los diarios nacionales unos días antes de su estreno. Véase Excelsior, Aviso Publicitario (6 jun. 1958).

39 Título de la telenovela: Senda Probibida. Director: Rafael Banquells. Productor: Jesús Gómez Obregón. Escritora: Fernanda Villeli. Protagonistas: Silvia Derbez, Dalia Íñiguez, Héctor Gómez, María Idalia y Francisco Jambrina. Realizador: Canal 4 - Telesistema. Año de emisión: 1958.

Jambrina, como el jefe de Nora, Dalia Iñiguez, como la esposa engañada, y Héctor Gómez, como el hijo del jefe. 
expectativa, Excelsior anunciaba que sería una historia contada en episodios de lunes a viernes, que sería diferente al teleteatro ${ }^{40}$ y la serie, ${ }^{41}$ que el esquema ya había sido probado en Brasil, Cuba y Venezuela, y que tendría muchas similitudes con las populares radionovelas. ${ }^{42}$ "Se abre la era de las 'telenovelas' ¡Jesús!” [...] "Nunca antes la TV de México había transmitido diariamente una telenovela, al estilo de las radionovelas que tanto auditorio tienen.". ${ }^{43}$ Novedades pronosticó una respuesta positiva en buena parte de los espectadores: "va a ocurrir que el teleauditorio se interese

${ }^{40}$ El teleteatro fue uno de los primero géneros televisivos. En términos prácticos consistía en la adaptación de representaciones teatrales para la televisión. Su debut fue atropellado, pues se carecía de recursos técnicos para hacer los montajes en un formato de televisión. Las primeras realizaciones en México fueron Teatro Selecto Packard y Teatro Fábregas. Ahora bien, el teleteatro se diferenció de la telenovela en términos técnicos y de estructura argumental. Si bien los dos pueden acudir al melodrama, entendido como género dramatúrgico, el primero se ve obligado a presentar una historia completa, con inicio y desenlace, en una sola emisión, apoyado en recursos histriónicos, escenográficos y de dirección propios del teatro; mientras que el segundo lo hace en varios episodios, enlazados entre sí - que no necesariamente tienen inicio y desenlace independiente - , con continuidad de un mismo argumento desde el primero hasta el último capítulo. Para teleteatros en México véanse Reyes de la Maza, México sentimental, pp. 12-13 y BAUche, "Del teleteatro a la telenovela". ${ }^{41}$ La serie televisiva es un producto compuesto por varios episodios, cada uno de los cuales relata una historia diferente con inicio y desenlace. Aunque se mantienen los personajes principales y se guarda continuidad, cada capítulo conserva independencia argumentativa del otro. En el caso de los años cincuenta, las series transmitidas en México eran producidas en Estados Unidos.

42 "Hoy empieza en TV mexicana la modalidad de las series en episodios", Excelsior (9 jun. 1958).

43 "Primera serie novelada por TV", El Universal (3 jun. 1958). 
profundamente $[\ldots]$ en cada uno de dichos personajes, los que de seguro, tratándose de los 'buenos', van a adquirir una popularidad excepcional”44 (véanse las figuras 1 y 2).

Figura 1

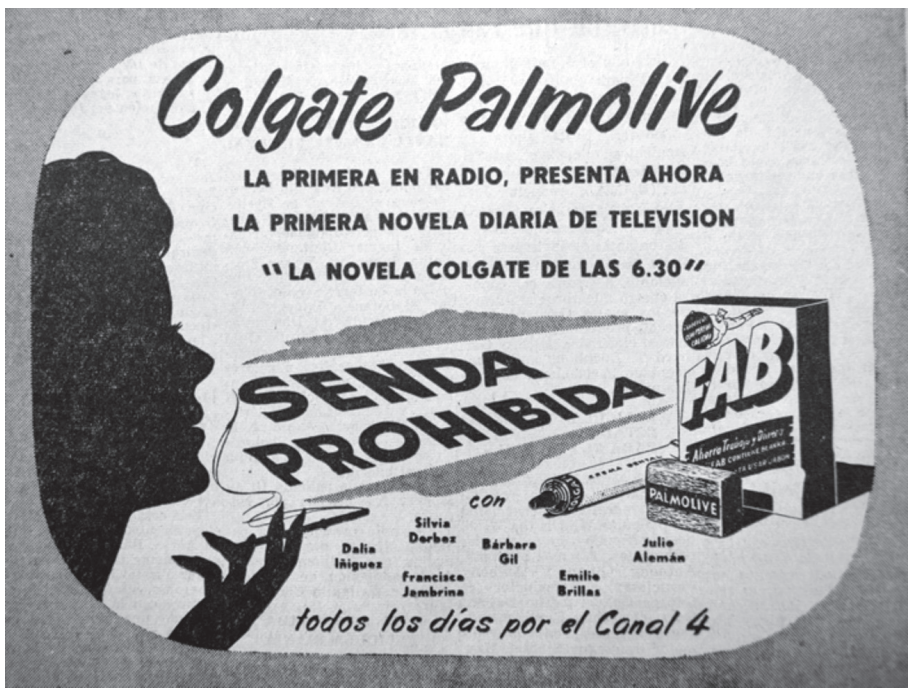

Publicidad de Senda Probibida, Excelsior (9 jun. 1958), p. 6-B.

Figura 2

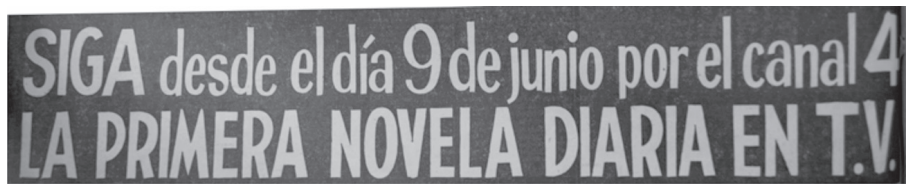

Anuncio de Senda Probibida, Excelsior (8 jun. 1958), p. 3-NC.

44 "Impacto en la TV es el inicio de la novela”, Novedades (10 jun. 1958). 
"Se convertirá en un programa apasionante", continuó Novedades. ${ }^{45}$ Parte de esa percepción se asociaba con el antecedente de la radionovela, pues Senda Probibida fue escrita por Fernanda Villeli, autora mexicana de series radiofónicas a quien le encargaron adaptar una historia suya de radio para televisión. En capítulos de media hora, el producto fue un experimento que empezó a demandar recursos tecnológicos, especialización y profesionalización exclusivos. La pantalla chica solía ser considerada por la crítica, $\mathrm{y}$ en especial por el cine mexicano, actores, ${ }^{46}$ directores y productores, como una industria de baja calidad, carente de valor artístico y con poco estímulo y competencia. ${ }^{47}$ Escribir exclusivamente para televisión, como lo hizo Villeli, fue parte clave del desarrollo profesional de guiones, lenguajes, escenografías y estéticas del medio. La telenovela, al emitir diariamente un episodio distinto, en vivo y sin apuntador, exigió profesionales de la actuación, dirección y producción de amplia trayectoria. ${ }^{48}$ No era suficiente con reproducir las fórmulas de la radio, el teatro y el cine en la pantalla chica. Por ende, la telenovela fue uno de los primeros productos en delinear un carácter propio y auténticamente televisivo.

El nuevo experimento fue patrocinado por la compañía Colgate-Palmolive, repitiendo el esquema estadounidense de financiar las soap-opera - por considerarlas propias de amas de casa, principales consumidoras de los detergen-

45 "Impacto en la TV es el inicio de la novela", Novedades (10 jun. 1958). 46 "Los actores de cine temen quemarse en TV", El Universal ( $1 \stackrel{\circ}{\circ}$ jun. 1958).

47 "Falta estímulo y competencia a la TV. Por eso tiene baja calidad", El Universal (2 jun. 1958).

48 Bauche, "Del teleteatro a la telenovela", p. 158. 
tes $-{ }^{49}$ En prensa, el anuncio publicitario de Senda Probibi$d a$ mostraba una bolsa de detergente Fab, una crema dental y una barra de jabón de ropa al lado del rostro de perfil de la protagonista, con un cigarrillo en la mano. Se trataba de una imagen de contrastes en la que se mostraba a la mujer desde la faceta del hogar, encargada del aseo de la casa y del cuidado de la higiene personal y de su familia, y al mismo tiempo, la mujer desde los placeres de fumadora y seductora - "prohibida" y provocadora-. Desde el inicio, los estereotipos femeninos y en general, la exploración del mundo de las mujeres fueron la principal fuente de "inspiración" para los argumentos de las telenovelas mexicanas. ${ }^{50}$ En razón del patrocinio, el melodrama tomó el sobrenombre de "la novela Colgate de las 6:30".

Ahora bien, en contra de la percepción optimista de los periódicos, los ejecutivos de Telesistema dudaban de la efectividad del producto. Fue así como el publicista Jesús Gómez Obregón, alto directivo de Colgate-Palmolive, se dio a la tarea de convencer a Azcárraga de las bondades del proyecto. En principio éste se negó, y fue sólo en su ausencia, debido a un viaje a Europa, que se pudo iniciar con el experimento. Para cuando el propietario de Telesistema llegó de su viaje, la telenovela ya estaba al aire. ${ }^{51}$

49 Reyes de la Maza, México sentimental, p. 15.

${ }^{50}$ Los extremos opuestos de los estereotipos femeninos, que según Julia Tuñón presentó el cine mexicano en los años cuarenta y cincuenta, se reprodujeron en el nuevo género televisivo desde su estreno. Se trataba de la mujer devoradora, que despierta los "temores masculinos", y la madre gestora, "que media con las esferas supremas". Tuñón, Mujeres de luz y sombra en el cine mexicano, p. 75.

51 Bauche, "Del teleteatro a la telenovela", pp. 156-157. 
El éxito del nuevo género no fue inmediato. El eje del entretenimiento continuaban siendo el cine y la radio. El espacio de publicidad, notas y secciones de prensa dedicadas a estas dos actividades, además de la circulación de publicaciones especializadas, evidenciaban la supremacía que conservaban frente a la televisión. De la programación del nuevo medio, los favoritos parecían ser las series estadounidenses, los musicales, los teleteatros y las comedias, tanto en $1958^{52}$ como en 1966, así lo comprueban mediciones como "Los diez favoritos de la televisión", ranking que publicaba cada semana Tele-Guía, con base en la opinión de los lectores. ${ }^{53}$ Solo hasta el final de la década de 1960, la preferencia por el medio y por la telenovela empezó a perfilarse como dominante entre el auditorio. La Encuesta Nacional sobre Radio y Televisión de 1971, que segmentó su consulta en grupos diferenciados de anunciantes, agencias publicitarias y público, evidenció el fuerte influjo de la televisión en solo 21 años de existencia. ${ }^{54} \mathrm{Al}$ indagar qué medio de comunicación había tenido mayor influencia en "la vida y costumbres de los mexicanos", $51 \%$ de los anunciantes con-

${ }^{52}$ Los ratings de abril de ese año señalaron que la primera puntuación era para el teleteatro dominical Telecomedia, de Manolo Fábregas, seguido por Las estrellas y usted y el programa Clavillazo. Véase "Dos millones de televidentes", El Universal (15 jun. 1958).

${ }^{53}$ En la revisión aleatoria de dichos rankings, para 1963, 1965 y 1966, los primeros lugares siempre eran ocupados por los programas Cómicos y canciones y Sonrisas musicales. Las telenovelas no solían salir en tal listado. Véase "Los diez favoritos de la televisión", Tele-Guia (1963-1966). ${ }^{54} \mathrm{La}$ encuesta fue realizada por la Facultad de Comercio y Administración de la Universidad Nacional Autónoma de México, bajo la dirección y coordinación general de José A. Fernández Arena. Se realizó un sondeo de opinión a 27920 personas, 108 entrevistas a anunciantes y se consultaron 45 agencias de publicidad. 
sultados señaló que la televisión, frente a $18 \%$ de la radio, $17 \%$ del cine y $8 \%$ de los periódicos, entre otros; $67 \%$ de las agencias publicitarias optaron por la televisión, seguida de la radio con $15 \%$ y el cine con $5 \%$; en contraste, una proporción menos dispar entre la opinión del público matiza esta tendencia y da más reconocimiento a otros medios, aunque insiste en definir a la televisión como el más influyente, con $30 \%$ de los encuestados, seguida del cine con $20 \%$, la radio con $18 \%$ y los periódicos con $16 \%$, entre otros. ${ }^{55} \mathrm{Al}$ indagar sobre cuáles programas de televisión eran los de su preferencia, con pequeñas variaciones, los anunciantes, las agencias y el público coincidieron en las "novelas", seguidas de los musicales, las películas y la programación deportiva. ${ }^{56}$

Figura 3

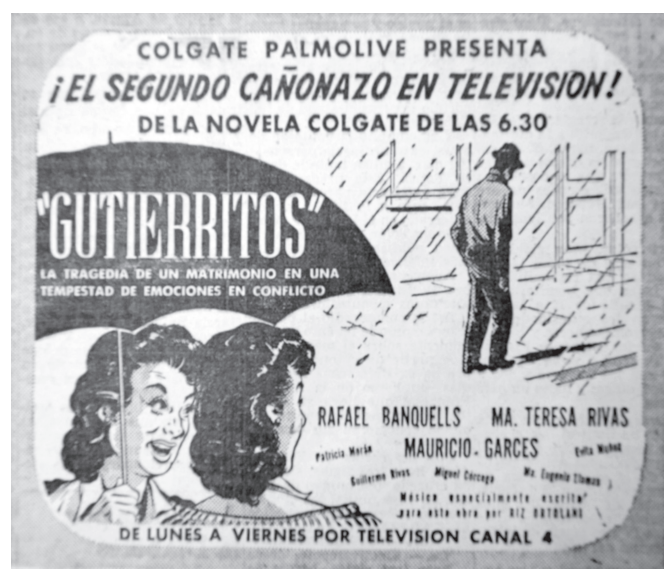

La publicidad de Gutierritos, Novedades (18 ago. 1958), p. 7.

${ }_{55}$ Encuesta nacional sobre radio y televisión, pp. 58-59.

${ }^{56}$ Encuesta nacional sobre radio y televisión, pp. 31-32. 
De la encuesta realizada en nuestra investigación a los estudiantes de la Universidad de la Tercera Edad, solo 2 personas de 53 recuerdan haber visto Senda Probibida. En el caso de las entrevistas, ninguno de los consultados manifestó haberla visto. No obstante, 29 de los encuestados sí recuerdan haber visto la segunda telenovela transmitida en México: Gutierritos, ${ }^{57}$ la historia de un hombre trabajador y dócil, maltratado por su ambiciosa esposa y traicionado por su mejor amigo (véase la figura 3). El viernes 15 de agosto de 1958 concluyó Senda Probibida y el lunes siguiente, 18 de agosto, se emitió el primer capítulo de la nueva novela diaria, ${ }^{58}$ indicio de que el experimento no iba por mal camino. La fórmula se repitió: Rafael Banquells en la dirección, Colgate-Palmolive como patrocinador, el horario de las 6:30 p. m., de lunes a viernes, por el canal 4. Colgate presentó la publicidad con el eslogan: “ $¡ E l$ segundo cañonazo en televisión!” ${ }^{59}$ La historia también era producto de la adaptación de una radionovela escrita por Estela Calderón. En esta oportunidad, el director asumió el papel protagónico, con el personaje de Ángel Gutiérrez, en compañía de María Tere-

57 Título de la telenovela: Gutierritos. Director: Rafael Banquells. Escritora: Estela Calderón. Protagonistas: Rafael Banquells, María Teresa Rivas, Mauricio Garcés y Patricia Morán. Realizador: Canal 4 - Telesistema. Fecha de emisión: agosto de 1958.

La segunda versión televisiva de Gutierritos se realizó en 1965. Título: Gutierritos. Escritora: Estela Calderón. Director: Rafael Banquells. Productor: Valentín Pimstein. Dirección de cámaras: Antonio Fernández. Protagonistas: Rafael Banquells, María Teresa Rivas, Mauricio Garcés, Patricia Morán. Realizador: Canal 2.

58 "Lanzan Gutierritos con elenco estelar", Excelsior (18 ago. 1958).

${ }^{59}$ En esta ocasión el producto también se vendía por su música: "especialmente escrita para esta obra por Riz Ortolani”, señalaba la publicidad. 
sa Rivas, en el papel de Rosa, la esposa dominante, y Mauricio Garcés como Jorge, el mejor amigo del protagonista.

Después de 50 capítulos, Gutierritos finalizó con éxito. Así lo dejó ver la prensa, que aún confundía la telenovela con el teleteatro o la llamaba “serie". Al igual que Senda Probibida, Gutierritos se hizo en vivo y sin apuntador, en ausencia de la tecnología que permitía grabar y retransmitir los episodios. No obstante, fue tal la fama de la historia, que en julio de 1959 Banquells protagonizó la versión para cine con la actriz Elvira Quintana, ${ }^{60}$ y en 1965 el elenco original de televisión grabó de nuevo la telenovela, aunque con menor impacto.

Figura 4

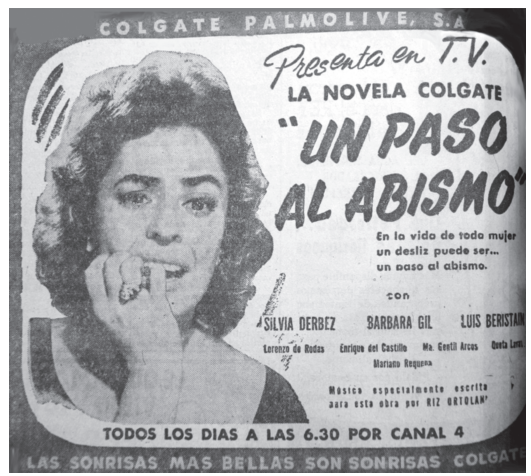

La publicidad de Un paso al abismo, tercera telenovela producida en México, Novedades (27 oct. 1958), p. 6.
Figura 5

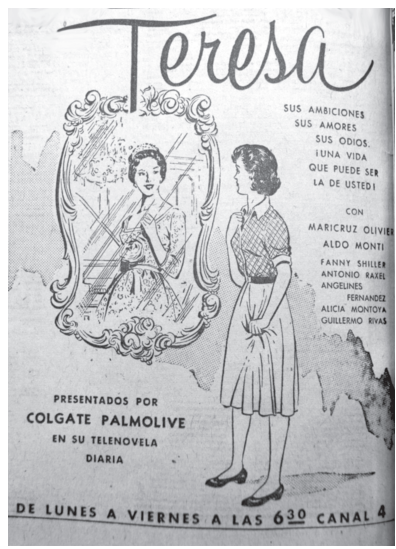

La publicidad de

Teresa, Novedades

(14 oct. 1959), pp. 2-3.

60 Senda Probibida también tuvo una versión para cine, protagonizada por Liliana Pardo y Enrique Rambal. 
El 27 de octubre de 1958 inició el tercer melodrama televisivo. Su realización parecía ser símbolo de la buena recepción que los dos primeros habían tenido, en especial Gutierritos. "Uno de los más grandes éxitos obtenidos en la televisión es el programa telenovela, que con patrocinio de Colgate-Palmolive, inicia hoy su tercera etapa, con la obra de Manuel Canseco Noriega, Un paso al abismo" ${ }^{61}$ De nuevo se presentaba a Silvia Derbez en el papel estelar, acompañada de un reparto proveniente del cine y el teatro (véase la figura 4). ${ }^{62}$ En esta oportunidad Derbez interpretaba a una muchacha dulce e ingenua; la actriz buscaba dejar a un lado la imagen de villana que le había traído Nora en Senda Probibida. El papel de "la amante" había conmocionado al público, acostumbrado a ver a Derbez en personajes de "niña buena" en el cine: "Llegaron a insultarme por teléfono cuando mi papel era de una mala mujer. Es grande verdaderamente el impacto que recibe el público”. Derbez parecía más cómoda con el papel de buena: "Ahora espero resarcirme y lograr una mejor opinión del teleauditorio". ${ }^{63}$

Más allá de la angustia, una historia de Mimi Bechelani, fue la cuarta telenovela producida por Telesistema. ${ }^{64}$ Pro-

61 "Con Silvia Derbez lanzan hoy la tercera telenovela", Novedades (27 oct. 1958).

Título de la telenovela: Un paso al abismo. Director: Rafael Banquells. Escritor: Manuel Canseco Noriega. Protagonistas: Silvia Derbez, Bárbara Gil, Enrique del Castillo y Luis Beristain. Realizador: Canal 4 Telesistema. Fecha de emisión: octubre de 1958.

${ }^{62}$ Los actores Luis Beristain, Bárbara Gil, Lorenzo de Rodas, María Gentil Arcos, Queta Lavat y Mariano Requena.

63 "Silvia Derbez está feliz con su papel dulce y humano en la telenovela", Novedades (28 oct. 1958).

${ }^{64}$ Título de la telenovela: Más allá de la angustia. Director: Rafael Ban- 
tagonizada por Dalia Ibáñez, Francisco Jambrina, Raúl Farell y Magda Guzmán, el melodrama inició el lunes 29 de diciembre de 1958. Frente al estreno, Palmolive afirmó que "es propósito de ellos seguir prestando ininterrumpidamente este tipo de teleteatros, ya que la aceptación que han obtenido de parte de los espectadores les alienta a continuar estas series". ${ }^{65}$ El 23 de marzo del año siguiente, se dio inicio a la quinta producción, Cadenas de amor, con Ofelia Guilmáin como protagonista. Según Novedades, la telenovela en México ya había conquistado "enorme y fiel teleauditorio". ${ }^{66}$ Para abril de 1959, Cadenas de amor ocupaba el segundo lugar de preferencia del público después de Mujeres célebres. ${ }^{67}$ En junio de 1959 inició Ha llegado un extraño, con María Douglas y Francisco Jambrina. En agosto de ese año se estrenó El precio del cielo, con María Teresa Montoya y Miguel Manzano. Hasta entonces la telenovela se había mantenido en el horario de las 6:30 p. m., de lunes a viernes, con una extensión no superior a 60 capítulos y patrocinador único (Colgate). No obstante, a partir de agosto aparecen en la programación dos producciones que se denominan "novela diaria”, en Canal 5: Cisco Kid, con Duncan Renaldo y Leo Carrillo a las 7:00 p. m., y Capitán de Puerto, con Barry Sulivan, a las 9:30 p. m., estrenando horario nocturno. En realidad se trataba de series de tele-

quells. Escritora: Mimi Bechelani. Protagonistas: Dalia Ibáñez, Francisco Jambrina, Silvia Suárez, Raúl Farell y Magda Guzmán. Realizador: Canal 4-Telesistema. Fecha de emisión: diciembre de 1958.

65 "Hoy se inicia la cuarta telenovela", Novedades (29 dic. 1958).

${ }^{66}$ En efecto, estos programas ya empezaban a encabezar los listados de audiencia y de "favoritos" para el público que publicaba Tele-Guía. 67 "Mujeres célebres y Tele-Novelas. Primeras en TV", Novedades (8 abr. 1959). 
visión producidas en Estados Unidos. ${ }^{68}$ Hasta entonces las telenovelas eran "exclusividad" de Canal 4. La competencia en Canal 5 y Canal 2 no presentaba programas con la misma estructura y carácter, producidos en México además.

Después del capítulo final de El precio del cielo, el martes 13 de octubre de 1959, Colgate presentó el primer capítulo de la telenovela Teresa. ${ }^{69}$ Original de Mimí Bechelani, contaba la historia de una joven universitaria, inteligente, que repudiaba su condición humilde y la de su familia. Preocupada por ascender socialmente, la joven decide seducir y engañar a hombres adinerados, rechazando el amor de un estudiante de medicina que vivía en su vecindad. Dirigida por Rafael Banquells, la octava producción de Colgate acudió a la tecnología del video-tape, que ya no exigía una realización en vivo y en directo y abrió el camino hacia la comercialización y retransmisión de las producciones televisivas (véase la figura 5). ${ }^{70} \mathrm{La}$ sucesión de melodramas hasta mediados de la década de 1960 es por demás amplia y

${ }^{68}$ La primera historia tuvo versiones en radio, cine y cómic, además de la televisiva entre 1950 y 1956 (aprox.). La segunda serie recogía las aventuras de un capitán de la marina en Nueva Inglaterra.

69 Título de la telenovela: Teresa. Director: Rafael Banquells. Productor: Jesús Gómez Obregón. Escritora: Mimi Bechelani. Protagonistas: Maricruz Olivier, Luis Beristain, Beatriz Aguirre, Alicia Montoya y Antonio Bravo. Realizador: Canal 4-Telesistema. Fecha de emisión: octubre de 1959.

${ }^{70}$ La telenovela que antecedió a Teresa fue la primera en grabarse en kinescopio, antecedente del video-tape. Se trató de El precio del cielo, de Fernanda Villeli, transmitida entre el 13 de agosto y el 12 de octubre de 1959. La novedad técnica de Teresa supone un punto de inflexión en la realización de este tipo de producciones y en el modelo de negocio de la televisión. BAUche, "Del teleteatro a la telenovela", p. 160. 
diversa. ${ }^{71}$ La exploración de nuevos horarios, canales de transmisión, temáticas y personalidades del cine y la radio consolidó un género con espacio propio.

Sin embargo, no hay que olvidar que el melodrama como género ya era una referencia conocida. Desde el siglo XviII su trayectoria se podía rastrear entre los folletines, las novelas por entregas, los circos, los teatros de feria, las radionovelas y el cine. ${ }^{72}$ La telenovela era su más reciente expresión. Desde sus inicios se concentró en consolidar una gran "complicidad con el público popular”, señala Martín-Barbero, elemento

${ }^{71}$ A Teresa le siguieron melodramas que aportaban nuevos elementos al género, como Las momias de Guanajuato (1960), dirigida y protagonizada por Ernesto Alonso, actor de cine que venía de trabajar con Luis Buñuel, ambientada en la época de la colonia; Doña Macabra (1963), considerada de humor negro, que contaba la historia de dos brujas, interpretadas por Amparo Rivelles y Ofelia Guilmáin, con la dirección de Alonso; Sor Juana Inés de la Cruz (1962) y San Martín de Porres (1964), bajo la modalidad de biografías, en especial de religiosos y santos; Maximiliano y Carlota (1965), considerada la primera telenovela histórica, producida por Alonso; La mentira (1965), de Caridad Bravo, protagonizada por Julissa y Enrique Lizalde; María Isabel (1966), escrita en historietas para la revista Lágrimas, Risas y Amor por Yolanda Vargas Dulché, fue leída por Silvia Derbez, quien propuso que se hiciera una versión televisiva; finalmente fue protagonizada por dicha actriz y producida por Valentín Pimstein; Corazón salvaje (1966), una historia ambientada en los primeros años del siglos Xx en una isla del Caribe, producida por Alonso, y El derecho de nacer (1966), producto de la radionovela del escritor cubano Félix B. Caignet, protagonizada por María Rivas y de nuevo dirigida y producida por Alonso, en el horario de las 9:30 p. m. Este último melodrama iniciaba con los dilemas morales de una joven que queda embarazada sin haberse casado con su novio y la determinación del padre de mandar matar al recién nacido. El niño queda con vida y es entregado a una empleada de la casa.

72 Para rastrear esta historia véase MARTín-BARBERo, Televisión y melodrama, pp. 42-57; Oroz, Melodrama, pp. 22-25 y para el caso del cine, PÉrez, El cine melodramático, pp. 23-27. 
que convierte al género en "espejo de una conciencia colectiva" y en espectáculo masivo. ${ }^{73}$ En su capacidad de conectarse con el auditorio y sus historias, de logar que los espectadores se reconozcan, el melodrama encuentra su sentido más básico. Por eso, mediante ellos es posible leer parte de las aspiraciones, las frustraciones, las obsesiones y hasta los delirios de sectores sociales de una época. Las imágenes que se crean de "otros", de problemáticas sicológicas, de contextos y condiciones socioeconómicas y culturales, de ciertas tradiciones y costumbres, de valores y principios morales, es decir, la referencia constante a estereotipos socialmente aceptados, son parte esencial del lenguaje del melodrama y sus recursos para lograr reconocimiento. Como en su momento el melodrama cinematográfico de mediados de siglo construyó y reafirmó estereotipos y se valió, al decir de Tuñón, de personajes que cumplieran funciones y retrataran tipos más que "complejidades personales", ${ }^{74}$ la telenovela hizo lo propio para alcanzar su identificación con los públicos y retratar en su narrativa parte de sus conflictos.

En consecuencia, el melodrama no es un simple e ingenuo derroche de lágrimas y risas. Este género, en sus diferentes

73 Martín-Barbero, Televisión y melodrama, pp. 40 y 42.

${ }^{74}$ El personaje-función que define Tuñón para el cine de los años cuarenta y cincuenta en México bien puede rastrearse en los recursos narrativos del melodrama televisivo clásico. "Se trata del hecho de que los personajes cubren funciones más que papeles humanos. Se prefieren los tipos, por su sentido popular y su eficacia narrativa, a las complejidades personales." En consecuencia, señala la autora, los personajes-función "aluden a categorías morales, implícitas y didácticas". "El bueno" y "el malo", la chismosa, la envidiosa, el peleonero, la ingenua, el chistoso, entre muchos otros, parecen ingredientes sin los cuales una receta no funciona a la perfección. TuÑón, Mujeres de luz y sombra en el cine mexicano, p. 79. 
expresiones, debe leerse en su propia dialéctica, como plantea Oroz, en relación con un momento histórico y en interrelación con un auditorio. ${ }^{75}$ En los años cincuenta, el melodrama era la raíz del cine popular: sus historias eran las que llenaban las salas del séptimo arte y con ellas se identificaba el público, aunque los críticos hayan subvalorado su impacto, afirma Oroz. ${ }^{76} \mathrm{El}$ melodrama cinematográfico de los años cuarenta y cincuenta y el auge de la radionovela son las referencias más acabadas y exitosas para el público que recibió Senda Prohibida en 1958. El género resulta familiar, aunque la experiencia de verlo y oírlo desde su casa, con transmisiones en vivo, en horarios antes no explorados, es uno de los principales factores de cambio que aparecen como novedosos para los mexicanos y que se integran a su día a día.

\section{EL TIEMPO: “LA HORA DE LA TELENOVELA”}

La tarde y la noche eran el horario más común para ver televisión. El estudio que reseña Excelsior para el Distrito Federal, en 1958, limita el rango entre las 3 p. m. y las 10 p. m. ${ }^{77}$ Las encuestas y las entrevistas realizadas para este artículo corroboran esta tendencia. ${ }^{78}$ "Como trabajábamos todo el

${ }_{75}$ Oroz, Melodrama, p. 18.

${ }^{76}$ Para esta autora, el principal problema del estudio del melodrama radica en la mirada displicente que los investigadores han tenido hacia él. En el caso cinematográfico, es el cine de autor de los años setenta, que calificó al melodrama como alienante y de consumo, el que condicionó los estudios posteriores. Oroz, Melodrama, p. 50.

77 "Hay 428.824 televidentes", Excelsior (12 jun. 1958).

${ }^{78}$ Las 10 entrevistas realizadas por Tele-Guía en 1966 señalan este mismo horario. En dichas entrevistas, ningún televidente señaló ver televisión en la mañana. 
día, solo hasta por la noche veíamos televisión." go de tiempo coincidió con el horario de "la novela Colgate de las 6:30", desde 1958, mientras que la franja de la noche se consolidó a partir de los años sesenta. Algunas entrevistas realizadas por Tele-Guía en 1966, a televidentes de la ciudad de México ${ }^{80}$ indicaban que la jornada de televisión podía extenderse incluso hasta terminar la programación, después de las 11 de la noche.

Por su parte, el horario matutino marcó una trayectoria interesante. La ampliación de la cobertura horaria de programación pasó de iniciar transmisiones a las 10:45 a. m., en 1955, a comenzar a las 7:15 a. m., 10 años después, en 1965. Los contenidos estaban dirigidos a las amas de casa. Sin embargo, la telenovela sólo apareció en esta franja hasta después de 1964, con emisiones diarias a las 11 a. m. o al mediodía, ${ }^{81}$ hora en la que posiblemente también se aten-

${ }^{79}$ Entrevista HCM. 1ํo de noviembre de 2012. Realizada por la autora.

${ }^{80}$ Usualmente empleados, de clase media y de familias de cinco a siete miembros.

${ }^{81}$ Una comparación entre la programación de 1955 y 1965 puede darnos idea de esta característica. Aunque los programas cambian, el esquema y el estilo se mantienen, con una única novedad destacable en la parrilla: la inclusión de la telenovela. Para el jueves 3 de marzo de 1955, la programación iniciaba a las 10:45 a. m. con Saludo, música y programaciones. A las 10:55 a. m. comenzaba Cuestión de minutos, lado amable de las noticias, y a las 11:00 a. m. El Club del hogar con Pérez Arcaraz y Ferriz, de una hora de duración. A la 1:30 p. m. se presentaban películas y se exhibían a esa hora Variedades del mediodía. Entre 2:30 p. m. y 4 p. m. había programas periodísticos (El mundo en cinco minutos, Tele-sintesis y Cine al día (noticiero fílmico). Para el jueves 5 de marzo de 1965, 10 años después, la programación iniciaba a las 7: $45 \mathrm{a}$. m. con Música selecta, presentando a la Orquesta de Dick Jacobs; continuaba con un noticiero matutino de 15 minutos a las 8:00 a. m., para proseguir con Reloj musical, un cortometraje; Gimnasia a las 9:00 a.m. y Revista Femenina a las 10:00 a. m. Las dos 
dían tareas domésticas relacionadas con la limpieza, la comida, el orden, las compras, el pago de cuentas, entre otros. En este caso no se formalizó un horario para los melodramas, como sí ocurrió en la franja de la tarde. Éstos se programaron según la conveniencia y ajuste con los musicales y revistas característicos del horario matinal. Ahora bien, al ampliar el rango de cobertura, haciendo más temprano el inicio de las transmisiones, se preveía la incorporación de otros televidentes a la franja: personas que antes de salir a trabajar, cumplir diligencias o estudiar, prendían el televisor.

Al comparar la programación de 1955 con la de 1965 es posible notar que para la noche el tiempo no se modificó sustancialmente, pues desde mediados de los años cincuenta la programación buscó llegar hasta la media noche. ${ }^{82}$ En 1965 , de lunes a viernes, la parrilla se cerraba con el noticiero de Federico de León en el Canal 2, a las 12:15 a. m., con una duración de 15 minutos. ${ }^{83}$ En cuanto a los contenidos, los

telenovelas de la franja iniciaban a las 11:00 a.m. y al mediodía Tres caras de mujer y San Martín de Porres, con capítulos diarios de media hora en el Canal 2. La mañana cerraba con otros programas de revista y variedad, musicales y noticieros de 15 minutos, a las 2:00 y 2:15 p. m.

82 Para 1955, en las noches de lunes a viernes se programaban variedades y revistas como Noches de circo, Bouquet de regalos y Ayer y hoy, en el Canal 2, y Optimismo y Alegría en el Canal 4 a las 10 p. m. y programas musicales como Velada musical, en el Canal 4, y Música inolvidable, en el Canal 2. Lo más similar a un programa dramatizado era Mi historia favorita, transmitido a las 8:30 en Canal 4. Este último canal cerraba programación con Cuestión de minutos a las 11:15, mientras que el Canal 2 concliía con Cine en su casa y Cine de la TV, a las 11:20 p. m., en Canal 4. "Programación", Tele-Guia (3 a 9 mar. 1955).

${ }^{83} \mathrm{Al}$ igual que en 1955, en la noche se emitían programas de variedades, cómicos y musicales, concursos como Memorice y capitalice, películas cortas, periodísticos como Revista mexicana de la cultura y Opinión 
programas estaban diseñados para un público familiar, preferiblemente adulto, donde predominaban los musicales, las comedias, las revistas de variedades, series estadounidenses y películas. Los noticieros a las 11:00 p. m., en el Canal 2, se mantuvieron tanto en 1955 como en 1965 y solo hasta 1966 la telenovela se integró a la franja nocturna. ${ }^{84} \mathrm{Su}$ primer gran éxito llegó el 7 de noviembre con la transmisión de El derecho de nacer. Este melodrama incursionó en el horario de las 9:30 p. m. y las transmisiones eran tres veces por semana: lunes, miércoles y viernes. En este caso, el melodrama extendió su promedio de duración, pues pasó de un promedio de 60 capítulos a los 100, que con tres emisiones por semana permitía desarrollar la historia en ocho meses y medio de transmisión, aproximadamente (véase la figura 6).

Figura 6

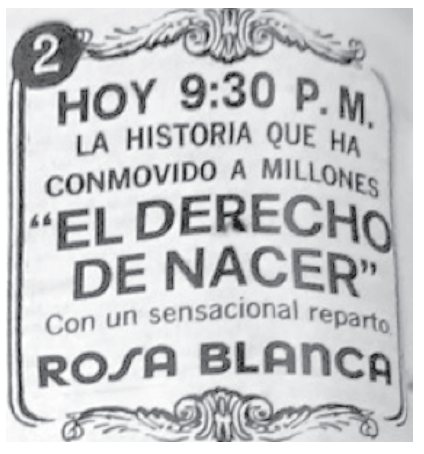

Anuncio de

El derecho de nacer, Tele-Guía (7 nov. 1966).

editorial, los dos de Canal 11, que si bien incursiona en 1959 en México, en Tele-Guía no aparecen sus registros sino hasta mediados de los años sesenta, y noticieros a las 11:00 p. m. en los canales 2, 4 y 5. "Programación", Tele-Guia (5 a 11 mar. 1965).

${ }^{84}$ La caldera del diablo, trasmitida por Canal 4, intentó crear un nuevo público con el horario de las 11:00 p.m. 
Para mediados de los años sesenta el tiempo de la telenovela ya se había modificado sustancialmente, pues se pasó de una emisión diaria de lunes a viernes a las 6:30 p. m., en 1958, a un promedio de siete a nueve telenovelas diarias distribuidas a lo largo del día. Para 1967, al aumento de los melodramas se sumó la modificación de los días de transmisión: de lunes a lunes. Tres a cuatro de las telenovelas eran transmitidas de lunes a sábado (6 capítulos semanales), la telenovela de las 9:30 p. m. se emitía solo tres días por semana y los domingos en la noche se presentaba un melodrama más, de repetición o de nuevo lanzamiento. En otras palabras, en 1967, de 17 horas aproximadas de programación diaria, de lunes a viernes, un promedio de 4 horas correspondía a la emisión de telenovelas. Aunque a mediados de los años sesenta el horario de las 9:30 de la noche apenas empezaba a consolidarse como el horario estelar, el ritual de ver la telenovela continuaba priorizando la franja de la tarde. El rango vespertino de telenovelas se extendió de media hora, en 1958, a dos horas y media, de 5:00 a 7:30 p. m., en $1967 .{ }^{85}$

${ }^{85}$ En la tarde de un miércoles de marzo de 1967, la franja de telenovelas iniciaba a las 5 p. m. con Rocambole, transmitida de lunes a sábado, protagonizada por Julio Alemán. Con un esquema similar, a las 5:30 comenzaba El juicio de nuestros hijos, con Carmen Montejo. A las 6:00 p. m. daba inicio "La víctima", transmitida de lunes a sábado, con la participación de María Teresa Rivas y Dalia Íniguez. A las 6:30 empezaba El usurpador, con Fernando Mendoza y Magda Guzmán. Finalmente, a las 7:00 p. m. se presentaba La frontera, con Emily Cranz, Julissa y Álvaro Zermeño, también con transmisiones de lunes a sábado. En la noche se transmitía El derecho de nacer, a las 9:30 p. m., los lunes, miércoles y viernes. Una de las novedades es la incursión de los domingos en la programación de las telenovelas: de 8:00 a 8:30 p. m. se presentaba Corazón Salvaje, la telenovela continuada, con exhibición de cuatro capítulos de 30. "Programación”, Tele-Guía (23 a 29 mar. 1967). 
¿Había saturación para el público "neófito”? Al parecer, sí. Pese a su novedad, el auditorio comprendió con rapidez cómo funcionaba la telenovela y tomó la decisión de incluirla en su rutina o rechazarla. De las 10 entrevistas hechas a televidentes en Tele-Guía, 4 manifestaban no seguir las telenovelas. De las 53 personas encuestadas, 18 expresaron no haber visto telenovelas o no gustarles el género. En los correos de lectores de Tele-Guía, una mujer pedía disminuir el número: "[...] también podrían quitar alguna comedia ya que dentro de poco todo van a ser telenovelas". ${ }^{86}$

El aumento de las emisiones hizo que el horario de las telenovelas coincidiera con la hora del quehacer, la hora de los juegos, la hora de tejer, la hora de merendar, la hora de cenar, la hora del descanso. El tiempo cobró varios significados a la hora de ver telenovelas. Era un tiempo de transición: "no había nada más que ver", "no había nada más que hacer". Era un tiempo de ocio: "el premio al final del día", sinónimo de descanso y de relajación, pues acostumbraba verse en un lugar cómodo - el sofá, la cama, el sillón-. Era el tiempo del entretenimiento que, combinado con el descanso, suponía un modo particular de emplear el tiempo libre. Y finalmente, era el tiempo de la simultaneidad, de combinar labores cotidianas; aquí se mezclaban la necesidad de tener un entretenimiento y la de cumplir con otras obligaciones del día a día. Realizar varias tareas mientras se veía la telenovela era una práctica común. Y aunque también había casos en los que se suspendía cualquier actividad para

${ }^{86}$ En la carta enviada a la revista, la lectora usa la palabra "comedia" y "telenovela" como sinónimos. Televidente María Cristina Palafox, TeleGuía (17 oct. 1963). Curiosamente la sección donde se publicaban las cartas de los lectores se llamaba "Páginas del director". 
concentrarse exclusivamente en el melodrama, es interesante destacar que de las encuestas realizadas, 63\% de las personas indicaron que, simultáneamente a la emisión, realizaban otras labores. En orden, las principales de ellas eran: hablar con la familia, jugar (niños), tejer (adultos), leer o estudiar, hacer el quehacer, trabajar, comer o cocinar. Incluso quedarse dormido remitía también a esa simultaneidad.

Ahora bien, el uso de este tiempo también estaba sujeto a las prioridades, hábitos y costumbres de la familia y sus miembros. "Íbamos con un vecino que nos dejaba ver televisión en las tardes, pero a más tardar a las 8 teníamos que estar en la casa", ${ }^{87}$ señaló un entrevistado aludiendo al caso de los niños. En la sección de lectores de Tele-Guía, un espectador le contestó a otro que se sentía agredido por los contenidos emitidos en el horario de la noche y el "pésimo ejemplo" que se daba a los infantes, en especial por los escotes de las presentadoras y las malas costumbres que la televisión estaba promoviendo:

[...] sería bueno preguntar a todos los falsos moralistas (Tleguías núms. 581-582), ¿qué hacen sus hijos despiertos después de las 8.30 p. m.?, ahí es donde debe aplicar su moral. [...] hay variedad en las transmisiones nocturnas y sólo toca al criterio formado de cada jefe de familia escoger programas y horarios que convengan al hogar. ${ }^{88}$

Evidentemente, el tiempo, y con él la programación de contenidos y la definición de horarios, estaban sujetos al tipo de espectador que la televisión misma estaba generando.

87 Entrevista JRF. 15 de noviembre de 2012. Realizada por la autora.

88 Tele-Guía (17 al 23 oct. 1963). 
El público infantil supuso la creación de franjas de horario especiales (usualmente las tardes de lunes a viernes), a las cuales se acopló dicho auditorio y creó hábitos en torno de la programación que tal horario ofrecía, como modificar la hora de descanso, el juego o la realización de tareas escolares. Estos cambios y las reacciones ante ellos son rastreables desde los inicios de la televisión. En 1953, por ejemplo, el semanario católico Unión alertaba sobre estas modificaciones y los problemas que traían para el público infantil, que "por sentarse a leer sus revistas o ver la televisión” desatendía las tareas escolares: "Donde hay televisión, ¿qué niño, o niña, o estudiante, resiste la tentación de esperar la cena a la hora de acostarse frente a una pantalla de televisión?”. ${ }^{89}$ Los cambios de hábitos y de horarios en función de la programación son rastreables en todos los públicos. Lo propio ocurre con el auditorio adulto masculino, seguidor de las peleas de box del sábado en la tarde, los partidos de futbol o las corridas de toros de los fines de semana. La televisión ofreció contenidos y horarios específicos, a los cuales los televidentes se ajustaron o no según sus intereses. Algunos espectadores llegaron, incluso, a crear "rituales" y rutinas que los convirtieron en un auditorio fiel, comprometido con la programación.

Las telenovelas fueron un producto que repercutió en el uso del tiempo libre de sus espectadores, en especial en el de las familias. Los cambios no son radicales, ni implicaron suspender tareas o costumbres tradicionales; sin embargo, promovieron la integración de la telenovela en la cotidianidad del día y de la casa. Modificaciones similares se habían experimentado en el ambiente familiar con la llegada de otras

89 “Televisiones y revistas”, Unión (29 nov. 1953). 
tecnologías de entretenimiento: "en los hogares, los sonidos del receptor se confunden con los del mundo cotidiano", señala Ornelas para el caso de la radio en los años veinte en México. ${ }^{90}$ Algunos entrevistados señalan que ante melodramas de mucho interés o ante la emisión del capítulo final de alguno de ellos, intentaban llegar más temprano a sus residencias o abstenerse de salir a la calle si no era necesario. Eventualmente los horarios de comida, cena o de dormir se modificaron en razón de la telenovela. Lo cierto es que al ocupar mayor espacio en la parrilla de programación y al consolidar franjas televisivas especializadas en el género, se produjeron modificaciones en los tiempos de convivencia familiar y sentidos diversos alrededor del uso de ese tiempo. Los realizadores de televisión estaban creando un público especializado en ciertos géneros, y a la vez el público estaba creando rutinas y hábitos de consumo en respuesta, favorable o desfavorable, a los contenidos televisivos que le ofrecían. ${ }^{91}$

\section{EL ESPACIO: ¿DÓNDE SE VEÍA LA TELENOVELA?}

Para finales de los años cincuenta, el televisor ocupaba un lugar "público" en la intimidad de la casa. Un lugar en el cual todos los miembros de la familia tenían la posibilidad

90 Este autor señala que los horarios nocturnos de la radio se integraron a las actividades familiares, constituyendo una suerte de "tiempo lento", previo a la hora de dormir, asociado con el descanso y la atención silenciosa a los sonidos que salían del receptor. ORNELAS, "Radio y cotidianidad en México", p. 157.

91 De Certeau plantea que no es suficiente con detenerse en la producción de la imagen. Para captar sus múltiples significados, es preciso rastrear los procesos de utilización que el usuario hace de ésta. De CerTEAu, La invención de lo cotidiano, pp. xliii-xliv. 
de encontrarse. De las 53 personas encuestadas para el presente trabajo, $68.9 \%$ recuerdan que el primer televisor que tuvieron se ubicaba en la sala, $18 \%$ lo ubicaron en el "cuarto de estar”, mientras que $4.9 \%$ le dieron un lugar en el comedor. Es decir, 91.8\% recuerdan haber ubicado el aparato en un lugar que podría considerarse "común" o compartido por todos en la familia, mientras que el $8.2 \%$ restante lo situaron en el dormitorio de los padres o en el propio, quizá en el lugar más "privado" de dicha distribución.

Para quienes adquirieron un segundo televisor durante los años sesenta, la historia tiene un esquema similar: se privilegian los espacios comunes, aunque con menos énfasis. "A mí me tocó comprar la segunda televisión, era una Sony, en blanco y negro [...] Estaba trabajando, yo creo que tenía unos 25 años, como en el 68 [...] Las teles no las cambiábamos seguido, solo hasta cuando se amolaban [...] La pusimos en esta sala. Aquí todos nos reuníamos." ${ }^{92}$ De las encuestas realizadas, $29.2 \%$ ubicaron el segundo televisor en la sala, $29.2 \%$ lo hicieron en la "sala de estar" y $12.5 \%$ en el comedor. Respecto a su ubicación en el dormitorio de los padres, la diferencia pasó de $4.9 \%$ con el primer televisor a $20.8 \%$ con el segundo. En este último caso, no deja de llamar la atención que el hincapié en el segundo telerreceptor esté en la habitación de los padres, no en la de los hijos. Esta condición marca una jerarquía y a la vez una posible modificación del sentido del espacio, en tanto un lugar "privado" o individual de la casa se va convirtiendo en "común" o "compartido", en un lugar de encuentro para el resto de la familia. No era de extrañar que a causa del televisor la habitación

${ }^{92}$ Entrevista ECM. 1ํ de noviembre de 2012. Realizada por la autora. 
de los padres se transformara en un lugar transitorio de descanso y reunión de otros miembros del hogar.

En ese esquema, ver una telenovela implicaba, por lo general, promover un plan familiar. Sobre todo para la franja del final de la tarde y la noche. El hecho de que el televisor soliera estar en la sala facilitaba esta acción, tanto por la distribución del espacio - que permitía disponer sillas y sofás - como por el significado de tener un lugar para compartir. En la organización de la sala, alrededor del televisor, usualmente había jerarquías y pertenencias. La silla más grande o más cómoda se asignaba a algún miembro especial de la familia, ese lugar tenía "nombre propio". De ahí que sea común señalar la pertenencia de los lugares: ${ }^{93}$ "esa es la silla del abuelo", "ese es el sitio de mi papá”, “éste es mi lugar”. "Los niños por lo general se sentaban en el piso, en fila, adelante, o sobre unos cojines, detrás estaba el sillón, donde se ponían los adultos." ${ }^{\prime 4}$ Sin embargo, las telenovelas no atraían a todos los niños, por lo que esta distribución era más común para otro tipo de programas, como los deportivos o musicales. Teniendo en cuenta que para los niños la hora tradicional de ir a dormir estaba entre las 8 y las 8:30 p. m. ${ }^{95}$ las telenovelas, y la programación posterior a esa hora se orientaban a los adultos. En la noche, la sala se compartía con los hermanos mayores, cuñadas y yernos, padres o abuelos: "yo me acuerdo que con mis hermanos nos quedábamos hasta tarde viendo películas y series”. ${ }^{96}$

\footnotetext{
93 Sobre el espacio doméstico destinado para la televisión se puede consultar BARrios, Televisión, telenovelas y vida cotidiana, pp. 21-25.

94 Entrevista ECM. $1^{\circ}$ de noviembre de 2012. Realizada por la autora.

95 Según se puede deducir de las fuentes consultadas: entrevistas y revistas.

96 Entrevista NIB. 10 de noviembre de 2012. Realizada por la autora.
} 
Cuando no había televisión en la casa, las fuentes permitieron identificar varias alternativas: primero, ser invitado por un familiar, amigo o vecino a ver un programa de televisión en su casa. Un televidente de Tele-Guía, en octubre de 1963, escribió una queja - por demás sarcástica- que permite identificar esta costumbre:

Los modestos televidentes de ésta su vecindad, donde diariamente nos reunimos un grupo de 15 a 20 personas para disfrutar con el aparato de televisión de un servidor, queremos expresar nuestras más expresivas gracias y felicitaciones a los productores del programa Glammur por haber tenido la buena idea de quitarlo del aire. ${ }^{97}$

Firmaban, inquilinos de Chimalpopoca 83, en la ciudad de México.

Es decir, la televisión también se veía entre vecinos, conocidos, familiares o amigos, hasta reunir, incluso, grupos numerosos, como en el caso de esta vecindad en el Distrito Federal. Por ende, entre los espectadores congregados había afinidad en gustos y una mínima coordinación que les permitía encontrarse en un lugar y hora específicos, coincidir en la programación y compartir un espacio.

La segunda opción era pagar por ver televisión con un vecino o conocido.

Solo dos personas tenían televisión en mi colonia, y esas personas hacían negocio con eso. Como nos encantaba ver el cuento de Cachirulo, los niños pagábamos 20 o 25 centavos para que

97 “Sección páginas del director”, Tele-Guía (1ª a 9 oct. 1963). 
nos dejaran entrar. Era una alegría muy grande. Todos cantábamos antes de que empezara el programa. Y ahí tenía la señora dulces, refrescos, chocolates para que le compráramos. ${ }^{98}$

Manolo Fábregas, director y productor de los teleteatros más exitosos de los años cincuenta, comenta que le llegaban cartas donde la gente le agradecía porque "gracias al programa estaba pagando su casa, ya que como había muy pocas televisiones, cobraba $\$ 2.00$ la entrada y ponía sillas en la sala, como si fuera teatro y los domingos juntaba su renta". ${ }^{99}$ Esta modalidad implicaba hacer un uso lucrativo del telerreceptor. El aparato no era solo para el entretenimiento familiar, sino para el negocio familiar.

Por último, la tercera opción era ver televisión en un establecimiento público, como los supermercados, tiendas de abarrotes, negocios y los almacenes de electrodomésticos. "Cerca de la escuela había una señora con una tienda. Ella fue la primera que tuvo televisor. [...] Nos dejaba quedar por las tardes siempre que consumiéramos cualquier cosa, una paleta, algo de tomar, cualquier cosa." ${ }^{100}$ Detenerse a ver televisión detrás de las vitrinas de las tiendas departamentales, los supermercados y almacenes especializados también fue una práctica frecuente para quienes carecían del telerreceptor. ${ }^{101}$ Quizá las vitrinas comerciales fueron la primera fuente de contacto de los capitalinos con el televisor justo a

\footnotetext{
98 Entrevista RMT. 15 de noviembre de 2012. Realizada por la autora.

99 Entrevista a Manolo Fábregas por Laura Castellot de Ballin, Historia de la televisión en México, p. 130.

100 Entrevistas NIB. 10 de noviembre de 2012. Entrevista HCM. 1º de noviembre de 2012. Realizadas por la autora.

101 Fernández, “Fallas de origen”, p. 55.
} 
su arribo. En agosto de 1950, antes de la inauguración oficial del sistema, el Palacio del Hierro invitó a "demostraciones prácticas de la maravilla de la televisión”, en el sótano de su edificio anexo, para que el público conociera y disfrutara "del resultado de años y años de investigaciones”. ${ }^{102}$ “ El día ha llegado!”, señalaba el anuncio de la tienda departamental en Novedades. Igualmente fue común hallar televisores en restaurantes, centros comerciales, sistemas de transporte y salas de espera, entre muchos otros sitios. La diferencia es que dicha presencia pública de televisores no suele estar asociada al lucro inmediato por la tenencia del aparato. Su función es de entretenimiento y comodidad en un espacio público.

Para 1958 abundaba la publicidad que promovía la compra de televisores. Pese a que continuaba siendo un artículo de lujo, éste adquiría mayor popularidad y atractivo en los precios. Marcas como Silverstone, Philips, Westinghouse, Dumont, Skymaster, Stromberg, Packard Bell y Philco ofrecían aparatos con innovaciones tecnológicas y usos funcionales para atraer clientes. Por 108 pesos semanales, la Súper-Consola Majestic 1958 ofrecía tres aparatos en uno: televisor pantalla gigante (21 pulgadas), radio de 5 bandas y tocadiscos de alta fidelidad (4 velocidades, con amplificador de 12 watts y 6 bocinas), integrados en un mueble de madera, "que es un alarde de buen gusto", exaltaba el anuncio en prensa.

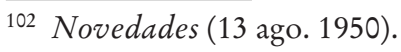


Figura 7

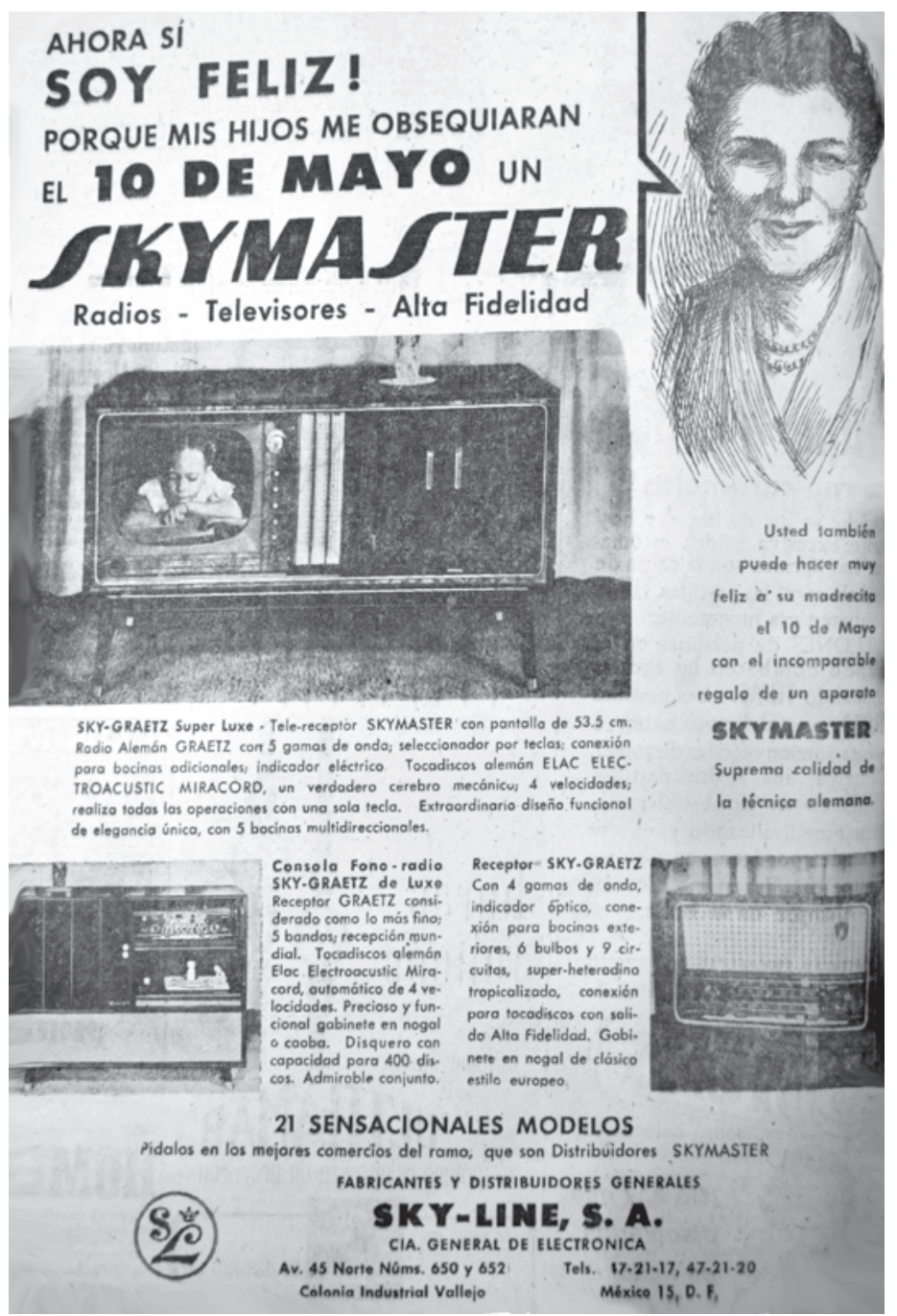

Anuncio publitario de Skymaster, Excelsior (4 mayo 1958). 
Las facilidades de pago eran comunes en las tiendas Sears y Liverpool, con créditos, preventas navideñas, descuentos y obsequios adicionales (radio o mesa) por la compra del televisor; incluso, se recibían radios y tocadiscos usados como enganche para el nuevo electrodoméstico. Para el día de la madre y el de navidad, la publicidad de televisores se intensificaba en la prensa. Para la conmemoración de dichas fechas, los anuncios acostumbraban asociar al televisor con el público femenino, con la unión familiar o con los deportes masculinos. Los promocionales impresos solían mostrar la imagen de una pantalla encendida donde dibujaban una mujer o la práctica de actividades deportivas - futbol, box, toreo-. Los días previos al 10 de mayo, por ejemplo, las campañas presentaban el televisor como el mejor regalo para las madres. "Un elegante presente para mamá", indicaba el almacén La estufa Universal S. A. El tema se vinculaba con una suerte de homenaje, un premio, la felicidad: "Usted también puede hacer muy feliz a su madrecita el 10 de mayo con el incomparable regalo de un aparato Skymaster", un modelo integrado de radio, T. V. y tocadiscos de alta fidelidad. "Algo digno de ella [...] adquiéralos en nuestros distribuidores autorizados”, decía la marca Zenith en Excelsior. Sin embargo, el esquema no era nuevo. El cine y la prensa, en especial, ya habían sido promotores del despliegue publicitario en virtud de "la madre" y la celebración del 10 de mayo. ${ }^{103}$ Con la televisión se aprovecha la novedad por el cambio tecnológico, se crea el imperativo de actualizarse, de no quedarse atrás ante los avances de la tecnología

103 A. Reyes, “Crimen y castigo”, pp. 316-319. Tuñón, Mujeres de luz y sombra en el cine mexicano, pp. 176 y 180. 
y, por supuesto, se alude a una nueva fuente de entretenimiento e información que las madres, en este caso, merecen tener a su alcance. El televisor se convertía en el obsequio ideal para la madre y al mismo tiempo en un nuevo recurso publicitario para promover su día y el despliegue comercial que éste representaba. La televisión era la nueva gran vitrina de exhibición de productos de consumo para toda la familia, además de la nueva plataforma de reafirmación de modelos y valores familiares, muchos de ellos tradicionales.

Para la publicidad de la época, acceder a la novedad tecnológica parecía ser sinónimo de felicidad. “¡Ahora sí, soy feliz! Porque mis hijos me obsequiarán el 10 de mayo un Skymaster." Ahora bien, era evidente que con la "felicidad" de la madre, el resto de la familia iba a encontrar entretenimiento y el estatus de reconocimiento que otorgaba tener la innovación tecnológica del momento. En realidad la madre parecía ser la excusa, pues el telerreceptor no iba a ser para uso exclusivo de ella. Siendo aún un lujo y concibiendo el acto de "ver televisión" como una actividad colectiva, el nuevo aparato tenía como función primaria el disfrute familiar. En otras palabras, el obsequio era para todos los miembros de la familia. La publicidad de Majestic resumía esta condición con realismo: "10 de mayo. Familia Majestic [...] familia feliz"104 (véanse las figuras 7, 8, 9 y 10). La felicidad era poder ver una telenovela o cualquier otro programa televisivo en la comodidad de la casa, sin necesidad de acudir a establecimientos públicos o a la casa de otros.

104 Excelsior (mayo 1958). 
Figura 8

\section{Z(O) de MUSTrO}

familia Majestic...
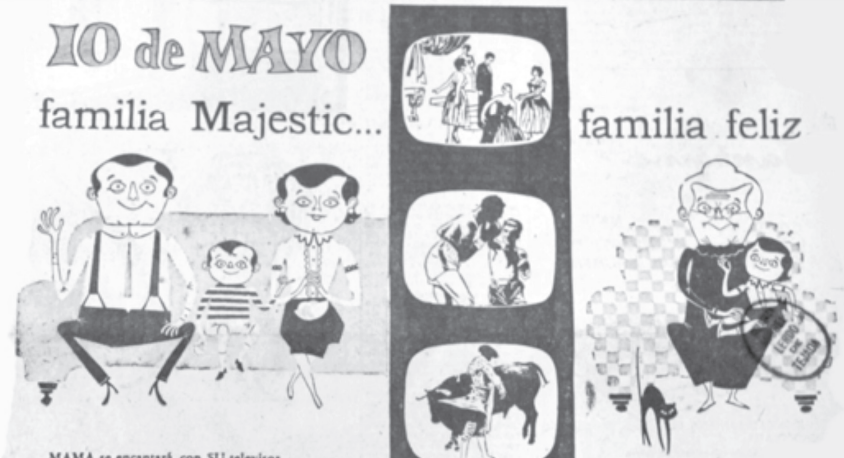

MAMA re eacanturt con SU televisot MAJESTIC....Poderoso Monarca del Aire, que garantiza: MEJOR IMAGEN MEJOR SONIDO $y$, eaturalmente. MEJOR INVERSION.

ITodo es MEJOR en el televiser MAJESTIC 1988!

SUPER-CONSOLA MAJES. TIC 1958 que ofrece por primera vet en Merico tres apartos en sno. Teterises. Ata Fiotidad y Rasio.

\section{TELEVISION}

Pantallo vigate aluminizada de $53 \mathrm{~cm}$. (21") 20 bulbos y transloumador blindabo

ALTA FIDELIDAD

Amplificador Bell de 12 Watts de salda. To. cadiscos Garrard modelo 88 de 4 veiocidades. automatico y manual 6 bocinus para produoir todos los tonos.

\section{RADIO}

Finisimo radio Majestic de 5 bandas con ab. cance mundial.

Un sensacional mutble que es un alarde de buen qusto.

TOMAMOS SU APARATO USADO A CUENTAI
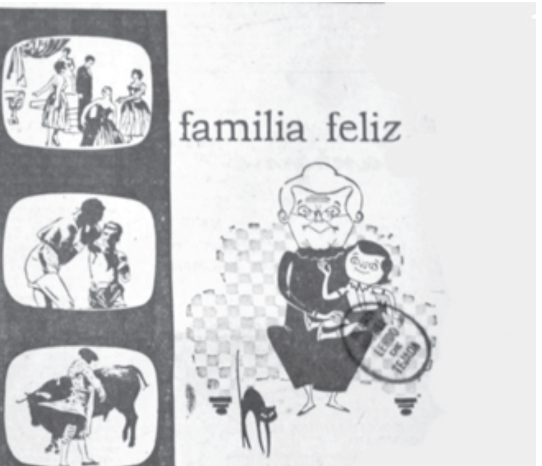

\section{familia feliz}

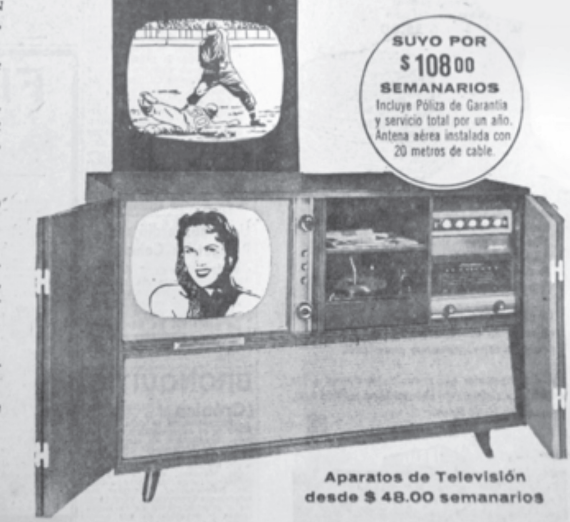

Visite nuestro stand en la Feria del Hogar

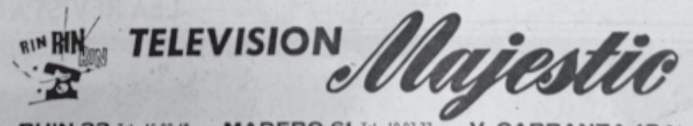

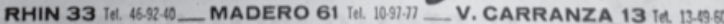

DISTRIBUIDORES MAJESTIC CON MISMOS PRECIOS Y PLAN DE VENTAS.

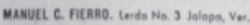

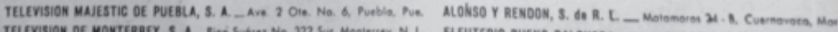

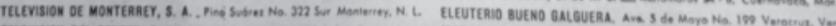

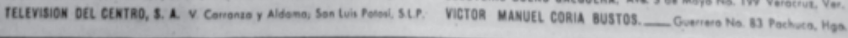

Anuncio publicitario de “Televisión Majestic”, Excelsior (6 mayo 1958). 
Figura 9

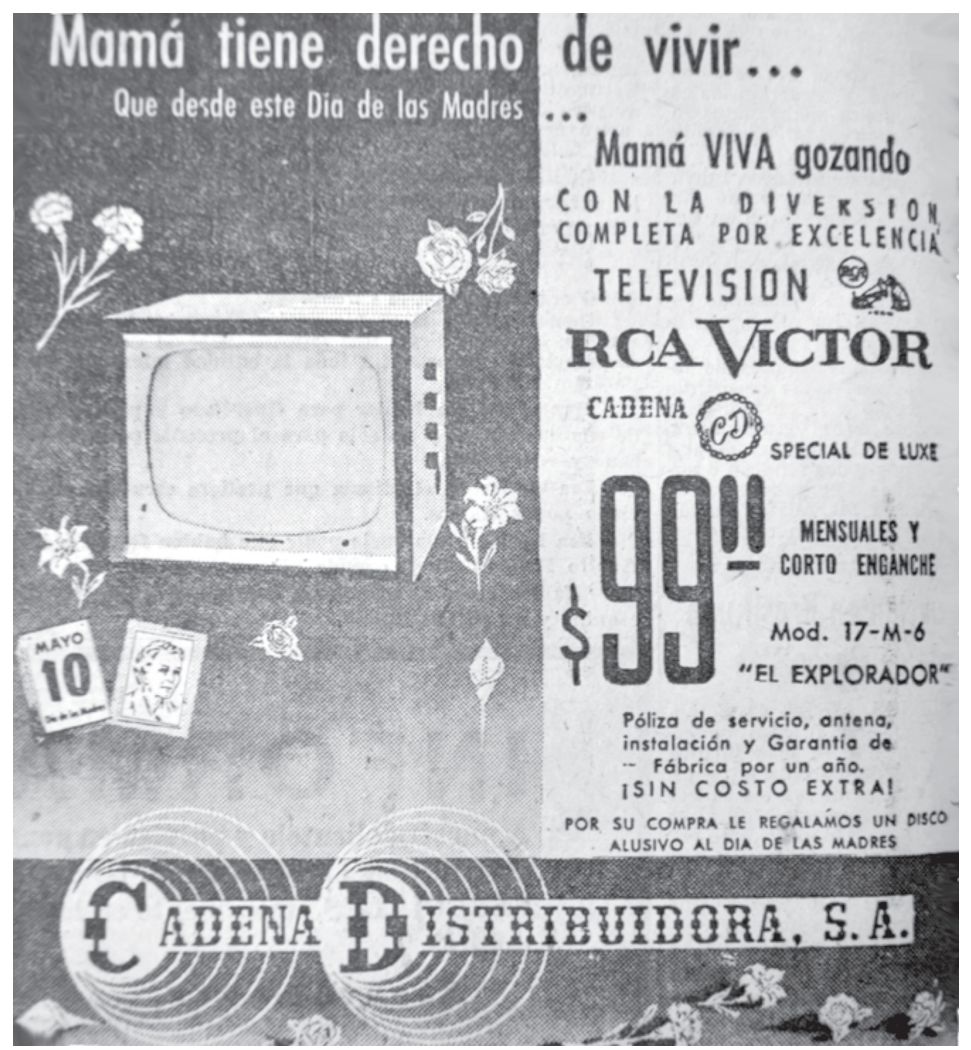

Anuncio publicitario Cadena Distribuidora S.A., Excelsior (4 mayo 1958). 
Figura 10

IN TODOS LOS MODELOS DE TV, LA ANTENA Y POLIZA SON EXTRAS.

EL TV MAS BARATO DE MEXICO ... I

\section{TV de mesa}

pantalla 43 cms. (17")

Con cinescopio aluminizado.

Bonito gabineto color caoba

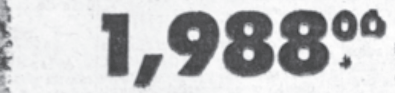

Dideticos controles al lado defecho. Es. 1. TV la brindard un sarvicio lon bueno

como los mós coros do esta tipo. Con lo GARANTIA SEARS.

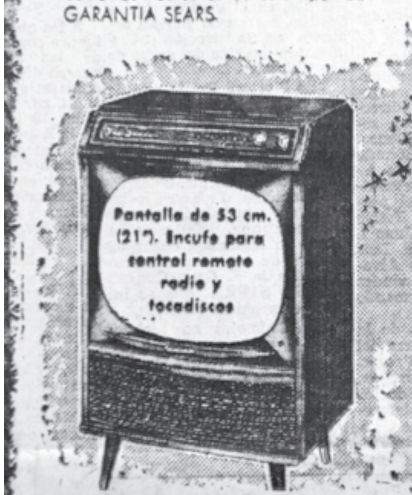

AHORRESE 907.00 TV consola SILVERTONE

Robaiado do 4,975.00, ahore śblor

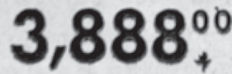

". Base giratorie. Poderoser

bocinas y voloctor lluminado

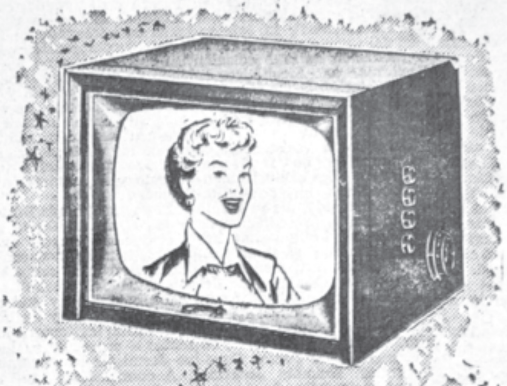

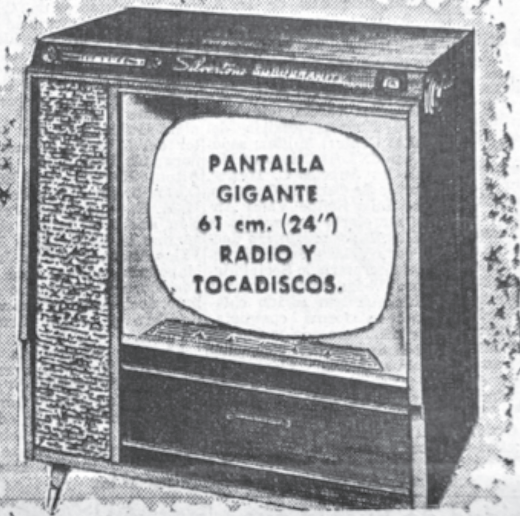

ECONOMICE 807.00

Talecombinación SILVERTONE

Normalmente su precio as 5.995.00, ahora

USE SU CREDITOI

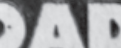

Anuncio de prenavidad en tiendas Sears. Ofrece distintos modelos de televisores Silverstone con facilidades de pago (créditos). Llama la atención la variedad de modelos y opciones de precio. Cinco meses después de ser estrenada la primera telenovela, Novedades (26 nov. 1958), p. 9-NA. 
La publicidad de los televisores estuvo en sintonía con los tipos de espectadores que los realizadores de contenidos televisivos estaban definiendo. La figura de la madre fue un recurso clave en la estrategia. En el caso de los televisores se trataba de "rendirle un homenaje" propiciándole entretenimiento. En el caso de la televisión, la telenovela fue la encargada de resaltar su lugar en la familia, de exaltar sus valores y exteriorizar sus frustraciones, de mostrar sus cotidianidades y jugar con sus matices y contradicciones - Madres egoístas era el nombre de una telenovela de los años sesenta-. Esta labor ya la había hecho el cine de oro mexicano, que otorgó a la maternidad la función de conceder cierta santidad a las mujeres y sublimar su presencia; ${ }^{105}$ en esta oportunidad la telenovela recurría a una fórmula conocida y exitosa, promoviendo estereotipos y dando una identidad femenina a su producto. La actriz mexicana Sara García se convirtió en la "madre de México"106 por los papeles que representó en el cine desde los años cuarenta, pero también fue la "abuela de México" por su participación en la televisión en los últimos años de su carrera. ${ }^{107}$ La madre ideal de los melodramas televisivos se erigió como base de la familia nuclear, gestora y protectora, sacrificada y virtuosa. Esta madre tiene su antítesis en mujeres que ejercen su maternidad con egocentrismo o ambición, por fuera de la familia nuclear, que abandonan a sus hijos, que denigran su condición. Estos personajes "antítesis" no cumplen otra función que reafirmar el ideal materno clásico. La madre en la telenovela

\footnotetext{
105 Tuñón, Mujeres de luz y sombra en el cine mexicano, p. 287.

106 Tuñón, Mujeres de luz y sombra en el cine mexicano, p. 179.

107 Sin mencionar que hasta la actualidad su imagen como abuela se usa en la publicidad de una popular marca de chocolate en México.
} 
es símbolo, temática, recurso y emblema, parte integral de la fórmula que la ha hecho miembro activo de la cultura popular de la segunda mitad del siglo xx en Latinoamérica.

En suma, la acción de ver la televisión se asoció con el entretenimiento familiar, con el encuentro y con el vecindaje. Ese acto colectivo propició espacios concretos de interacción. Para las décadas de 1950 y 1960, las fuentes permiten concluir que la televisión se veía en compañía, en lugares compartidos. Fue primordialmente un acto de reunión al que se le asignaron horarios, gustos, actuaciones y usos. La telenovela reprodujo esta práctica. El producto hacía énfasis en el público femenino y sus contenidos priorizaban los personajes de las mujeres, construyendo o reproduciendo estereotipos y tipos ideales en torno de éstas; sin embargo, el espacio por definición de los espectadores de estas primeras telenovelas mexicanas era más amplio, pues antes que otra cosa, lo envolvía un carácter colectivo y doméstico. Los horarios y la programación, las condiciones de vida familiar, la capacidad de acceso a un televisor y la novedad del producto promovían que la práctica se orientara a un acto compartido entre varias personas. El melodrama supo aprovechar estas condiciones y reproducir elementos de la vida doméstica y familiar donde todos se vieran identificados. Con el tiempo decide hacer hincapié en la figura femenina, tanto en sus argumentos como en su auditorio. "Convocan al consumidor en un escenario - el hogar, las relaciones amorosas, los hijos - que pertenece al ámbito de lo estrictamente privado e íntimo, donde presuntamente la mujer ha erigido su imperio". 108

108 Roura, Telenovelas, p. 37. 
EL TELEVIDENTE: GUSTOS, HÁBITOS Y COSTUMBRES

Al compartir la televisión se compartían también gustos o se negociaba la posibilidad de satisfacerlos. "Lo que más se veía era el box, los sábados en la tarde, y la lucha libre. Eso impactaba mucho a la gente. [...] Mi papá, los tíos, los hermanos y los trabajadores se reunían en la sala a ver la tele. [...] Yo creo que eran unas 15 personas", comenta una de las entrevistadas. ${ }^{109} \mathrm{Al}$ ser el televisor un objeto "de todos", era común que ver las telenovelas fuera un ejercicio de negociación.

En mi casa había disputas. A los varones no les gustaba ver la novela y a nosotras sí. A ellos les gustaba el box. Nos poníamos de acuerdo con el final. Cuando pasaban las peleas nosotras nos poníamos a hacer otras cosas [...] Después con el otro televisor sí cada quien veía lo que le gustaba. ${ }^{110}$

Con frecuencia, también se tenía que ver lo que gustaba a los mayores sin opción de negociar. "A veces veíamos lo que mi hermano mayor quería [...] Como él había sido el que había comprado la tele, nos decía: 'no vayan a prenderla sino hasta que yo regrese, porque me la descomponen', y pues sí, por andar prendiéndola alguien la descompuso", 111 señaló otra entrevistada.

Con frecuencia la elección de los programas de televisión estaba asociada con las jerarquías del hogar, la edad y el género y los códigos de comportamiento que en torno de éstos producían los realizadores, las autoridades morales y

109 Entrevista HCM. 1ำ de noviembre de 2012. Realizada por la autora.

110 Entrevista RMT. 15 de noviembre de 2012. Realizada por la autora.

111 Entrevista RMT, 15 de noviembre de 2012. Realizada por la autora. 
el público. En la sección de televidentes de Tele Guía, la niña Silvia Valencia se quejaba de los escotes de Elvira Quintana en Pasos triunfales y pedía no presentar tantos comerciales en la telenovela Madres egoístas. La respuesta de la revista fue tajante: "Las niñas no deben ver telenovelas, y ¿qué tanto sabes de los escotes de Elvira, de Los intocables y Surf side Six? que sólo son para adultos". ${ }^{112}$ La telenovela aún se movía entre la novedad de lo prohibido y las imposiciones de lo permitido. Las reglas del hogar y las convenciones sociales estaban detrás de esta disyuntiva: "Se cuidaba uno de que los muchachos no vieran esas telenovelas. Y se le apagaba la tele. Se les decía, 'no, eso no es para ti' ". ${ }^{113}$ Para los años sesenta, las telenovelas ya habían creado un público propio, familiarizado con el esquema narrativo, la estética y los actores y directores participantes. De neófito, este público había pasado a convertirse en "experto".

Sin embargo, las expectativas creadas entre consumidores de diferentes edades, género, gustos y hábitos, no siempre armonizaban con los códigos de comportamiento moral y las prácticas sociales de la época. La niña Silvia quería ver telenovelas - es más, asumimos que le gustaba verlas -, no obstante, las pautas de comportamiento para personas de su edad señalaban que no eran aptas para ella. Pese a esta advertencia, la niña Silvia terminaba viendo telenovelas y aún más, exigiéndole al realizador, por medio de una revista, que no abusara de los comerciales que incluía en ellas. Casos por el estilo pueden multiplicarse. Las contradicciones entre el público al que va dirigido un producto y el público que

112 Tele-Guia, (10 al 16 de octubre de 1963).

113 Entrevista ECM. 1º de noviembre de 2012. Realizada por la autora. 
finalmente lo consume son casi imposibles de registrar. Las mismas contradicciones ocurren entre las recomendaciones morales, educativas y cívicas que se plantean para los contenidos televisivos y los usos y prácticas cotidianas, domésticas y personales que el espectador termina asumiendo. Tener precisión histórica y poder documentar con detalle este tipo de hechos también resulta una tarea casi imposible. La teoría del consumidor propuesta por Michael de Certeau bien puede explicar el acto de ver televisión y la complejidad que encierra. ${ }^{114}$ No es posible definir al televidente como dócil y predecible, siempre hay una reacción. Es un consumidor que responde aceptando o rechazando un producto, según sus expectativas, intereses y criterio. El producto se “resignifica” en virtud de estas reacciones.

Para 1958, los estudios señalaban al Canal 2 como el de mayor audiencia (45.7\%), seguido por el Canal 4 (29.4\%) y el Canal $5(24.9 \%) .{ }^{115}$ Es decir, la telenovela no inició en la cadena con más auditorio (Canal 4), ni en el horario más exitoso. En un sistema de escasa competencia, como el que había generado la fusión de los tres canales de televisión en una sola empresa - Telesistema-, la telenovela surgió como un "ensayo-error" que no desafiaba a los programas ya consolidados en la parrilla. No obstante, la fórmula demostró que funcionaba. Fue así como en 1960 el Canal 2, el de mayor audiencia, comenzó a transmitir melodramas a las 6:00 p. m., horario y género hasta entonces exclusivo del Canal 4 y su patrocinador Colgate-Palmolive. El mismo año, el Canal 2 integró una telenovela al horario de las 7:00 p. m., Elisa,

114 De Certeau, La invención de lo cotidiano, pp. xlii-xliv.

115 “Hay 428.824 televidentes”, Excelsior (12 jun. 1958). 
protagonizada por Silvia Derbez, estrenándose en un horario más cercano a la noche. En 1961, Ernesto Alonso conformó "la primera barra de telenovelas para Canal 2 bajo el nombre genérico de La comedia bumana". ${ }^{116}$ A partir de entonces los programas dramatizados mexicanos se mantendrían en dicho canal, desplazando al Canal 4 y sin competencia alguna hasta mediados de la década de 1990. ${ }^{117}$ "Las comedias" (como el público acostumbraba llamarlas) se convirtieron en tema de conversación. Los personajes y las historias se llevaban a la mesa del comedor, a la cama, a la oficina, al supermercado, al salón de clases, a la calle. "A veces nos quedábamos platicando de lo que había pasado en el capítulo, o hacíamos cualquier comentario durante la telenovela."118 "Si la telenovela estaba muy buena, al otro día era uno de los temas en el trabajo" ${ }^{119}$ La frase "cuéntame en qué se quedó"120 o "qué pasó ayer”, hasta la actualidad, sirve de preámbulo para iniciar una conversación acerca de una telenovela. Quien no había visto el capítulo anterior buscaba ponerse al día antes de ver el episodio siguiente.

116 Cueva, Lágrimas de cocodrilo, pp. 66-68.

117 Fue en 1993 cuando apareció una nueva televisora comercial, T.V. Azteca, produciendo telenovelas. El primer melodrama del canal fue $A$ flor de piel, grabada en 1996. El mismo año se grabó Con toda el alma, Nada personal, un melodrama policiaco producido por Argos TV, Trictrac y Te dejaré de amar. Posiblemente su melodrama más reconocido fue Mirada de mujer (1997-1998), también bajo la producción de Argos. 118 Entrevista HCM. 1ํ de noviembre de 2012. Realizada por la autora. 119 Entrevista RMT. 15 de noviembre de 2012. Realizada por la autora. 120 Alrededor de esta frase, Karla Covarrubias et al. realizan un estudio etnográfico en México en diferentes grupos familiares para principios de los años noventa. Véase Covarrubias, Uribe y Bautista., Cuéntame en qué se quedó. 
La necesidad de saber sobre el curso de un melodrama, entre sus seguidores más fieles, produjo respuestas en las revistas especializadas en televisión, como Tele-Guía. El acercamiento a estas revistas es determinante para captar matices y percepciones del medio en otros espacios periodísticos, eventualmente entre los realizadores y participantes de las producciones y, sobre todo, entre algunos sectores del público que se pronunciaban enviando cartas a la revista. Para mediados de los años cincuenta, esta publicación contaba con el mismo esquema de su filial estadounidense, T.V. Guide, que entró en circulación en abril de 1953. El propósito era suministrar al público una guía completa de la programación semanal, con horarios y reseñas de los programas. Bajo este esquema también surgió Guía Tele Radio, que además de incluir la parrilla radial, clasificaba la programación por temáticas y géneros (infantil, noticieros, dramatizados, concursos, películas, deportes, entre otros). ${ }^{121}$ En el mercado también apareció $T V-54,{ }^{122}$ que hasta la década de los setenta ofreció el reporte semanal de programación televisiva, acompañado de una publicación adicional, en un formato más extenso, que incluía actualidad, crítica de televisión, reportajes y entrevistas. Todas estas revistas se produjeron en formato de bolsillo; en el caso de $T V$ - 54 en papel grueso, resistente, pensado para manipularse y trasladarse con regularidad en el transcurso de la semana. Sin embargo, la gran novedad de Tele-Guía fue incluir en sus páginas

121 Guí Tele Radio era editada a finales de la década de 1950 por Comunicaciones y Electrónica S.A., en México D. F., y tenía un costo de un peso. 122 El nombre de la revista cambiaba según el año. Por lo cual, en 1955, por ejemplo, pasó a llamarse TV-55. Era una publicación de Ediciones TV S.A., producida en México D. F. 
breves descripciones de los programas y avances de contenido de los dramatizados. La revista permitía conocer con antelación lo que ocurriría en las telenovelas en los siguientes siete días. Como un "clarividente", el espectador quería predecir qué ocurriría con la historia y descubrir capítulo por capítulo los giros de la trama, pero, al mismo tiempo, no descartaba la posibilidad de calmar su curiosidad leyendo los avances y preparándose para lo que vendría en el trascurso de los días. Se trata del "placer de conocer la revelación del secreto y la toma efectiva de partido ante las características y situaciones de las telenovelas". ${ }^{123}$ El espectador es "portador de un secreto", entre él y los personajes, y al mismo tiempo un "revelador de secretos" que desea conocer el destino de esos personajes y en ocasiones adelantarse a pronosticar el rumbo de la historia.

Como se señaló arriba, para principios de los años sesenta, los televidentes ya se consideraban expertos en el mundo de las telenovelas, pese a su reciente incursión. Los más asiduos espectadores opinaban en la revista, enviando cartas que se publicaban semanalmente. Sus comentarios permiten identificar un alto grado de familiaridad con el producto. Al menos hasta mediados de la década de 1960, son comunes los reclamos, las quejas, las sugerencias, las felicitaciones o los rechazos. No hay una línea única de opinión al respecto. Los televidentes a favor y en contra de un mismo hecho, personaje, actitud o producto se manifestaron vigorosamente en las páginas de Tele-Guía.

$\mathrm{Al}$ parecer, los espectadores se sentían con el derecho y la necesidad de opinar. Aunque desconocemos el criterio

123 González, La cofradía, p. 55. 
de selección de las cartas a publicar, la revisión sistemática de esta sección permite desmitificar la existencia de un televidente pasivo. Hay reacciones diversas, pues diverso es el auditorio. Quizá no en todos los ámbitos, edades, condiciones socioeconómicas o formación profesional se percibía la misma participación y familiaridad con el medio. Sin embargo, sí es evidente la presencia de acuerdos y desacuerdos con lo que aparecía cada semana en las pantallas. La telenovela es particularmente proclive a estas reacciones múltiples. Una televidente, conocedora de los detalles de los melodramas al aire, reclamaba a la revista: "anoten bien los capítulos de las telenovelas, pues a veces escriben en viernes lo que pasó el jueves", ${ }^{124}$ firmaba niña Iliana Font Chávez, ${ }^{125}$ de la colonia Narvarte. Eran recurrentes las molestias por la cantidad de comerciales: “ ¿no cree usted que en lugar de tantos comerciales tan fastidiosos, nos deberían dar oportunidad de gozar de nuestra telenovela favorita y de ser posible comerciales de buen gusto, por ejemplo, de dibujos animados?". ${ }^{126}$ Otra televidente se quejaba por los cambios de horario, que le impedían ver sus melodramas de costumbre. "Somos aficionados a ver la Reseña, pero ya no podemos hacerlo porque la proyectan a las 5:15 p. m., debería pasar como antes, a las 3:30 p. m., pues a muchas personas mayores les gusta ver las telenovelas.” ${ }^{127}$ Algunas cartas

124 Tele-Guía (17 a 23 oct. 1963), pp. 46-47.

125 Es común encontrar cartas firmadas por niñas. Sería interesante profundizar en los rangos etarios en los que se catalogaba como niño o niña a una persona.

126 Tele-Guia (24 a 30 oct. 1963), p. 46.

127 Reseña era un programa que proyectaba películas acompañadas de referencias y datos que ilustraban al público sobre el film. Con la modi- 
eran suscritas por varias personas: "Escribo a nombre de 26 vecinos de la Col. Sta. María, que anteriormente apagábamos nuestra T.V. cuando se presentaba el programa Pasos triunfales, ya que era detestable. En cambio ahora, con su nuevo elenco [...] disfrutamos de un buen programa". ${ }^{128}$ Los contrastes los propiciaba la revista en sus propias páginas, pues en la misma edición, otra televidente retomaba la controversia por los escotes de Elvira Quintana: “Todas las familias decentes estamos muy disgustadas [...]. Sería muy conveniente que la censura, al igual que prohibe ciertos programas por su contenido poco moral, fijara su atención en los exagerados escotes de esta artista y obligara a que tal programa se presentara en el horario en que las familias decentes ya están dormidas”. ${ }^{129}$ Firmaba la Sra. Elsa Zaragoza, en Av. Universidad 199. En definitiva, y aunque a mediados de la década esta sección de la revista se ve reducida, encontramos un sector del público activo, apropiado de su condición de televidente e involucrado con la telenovela. ${ }^{130}$ Los seguidores más asiduos demuestran en sus comentarios su conocimiento de las historias, los personajes, los horarios y hasta detalles de la producción. Para los primeros años de

ficación de horario, Reseña, que se presentaba en Canal 4, coincidía con la franja de telenovelas de la tarde. Al enfrentar los dos programas en el mismo horario, la televidente se veía obligada a dejar de ver uno de ellos. Tele-Guía (19 a 25 dic. 1963).

128 En favor del mismo programa hay otra carta firmada por 32 personas. Tele-Guia (10 a 16 oct. 1963).

129 Tele-Guí (10 a 16 oct. 1963).

${ }^{130}$ Incluso, al rastrear la sección por varios meses, se pueden encontrar lectores que escriben con cierta regularidad a la revista, haciendo alusión a la misma reclamación. Es el caso de Cristina Palafox, quien escribió en octubre y en diciembre quejándose por el cambio de horario de Reseña. 
la década de 1960, la telenovela ya se había posicionado en el gusto de los televidentes y los hábitos cotidianos de la familia. Esto le permitió ocupar un lugar en el entretenimiento y el uso del tiempo libre de los espectadores. Con el tiempo, estos gustos y hábitos fueron construyendo estereotipos en torno al público y el contenido del melodrama. ${ }^{131}$ Como actividad de entretenimiento, se asoció con la figura femenina y las amas de casa, pese a que eran seguidas por todos los miembros de la familia. El sondeo realizado entre personas de la tercera edad en la ciudad de México mostró que $17.8 \%$ consideraban a las telenovelas entretenimiento, $14.4 \%$ las veían como un producto hecho para amas de casa y $8.9 \%$ como un asunto de mujeres. La respuesta destaca los estereotipos, las contradicciones y las realidades creadas alrededor del melodrama. De los encuestados, $16.5 \%$ las definían como un reflejo de la realidad, mientras que $10 \%$ consideraban que únicamente "embrutecían" a las personas. Independientemente del gusto que se desarrolle por las telenovelas, siempre hay una percepción detrás. Estos resultados están caracterizados por el contraste. No hay una sola línea de interpretación frente a la recepción del auditorio: $8.9 \%$ de las personas consideraban que los melodramas

131 En ocasiones era referente y reflejo de la moda de la época, los peinados, el maquillaje, los accesorios, los dichos, los temas. La escenografía, precaria al principio, fue presentando modelos de distribución del mobiliario y estilos de vida. De las telenovelas, no era claro si éstas copiaban la vida cotidiana o si era la vida cotidiana la que intentaba copiar esquemas vistos en las telenovelas. Sin duda, estos son temas a abordar en futuras investigaciones, pues requieren una metodología diferente que permita captar cómo los contenidos de los dramatizados reflejaban o no la cotidianidad de la sociedad de la época, qué tan fieles eran a la realidad y qué licencias de ficción se permitían en este aspecto. 
eran para toda la familia, $10 \%$ los asociaban con el amor y las lágrimas y $4.4 \%$ afirmaban que sólo eran para gente sin educación. Vincular al melodrama con un solo grupo poblacional, condición socioeconómica, formación profesional o aspectos emocionales es un error.

\section{CONSIDERACIONES FINALES: LOS CAPÍTULOS PENDIENTES}

El melodrama es un género con historia propia. MartínBarbero se remonta hasta la Francia e Inglaterra de finales del siglo XviII para narrar cómo los espectáculos teatrales de feria, con temas de la literatura oral, dieron inicio al "espectáculo total" por el que se caracteriza el melodrama. ${ }^{132}$ Se trataba de un género que admitía reunir novela negra, epopeya, tragedia y comedia en una sola narrativa. El melodrama giraba en torno a dos ideas: el paso del desconocimiento al reconocimiento de la identidad y el anacronismo como retórica del exceso. "Todo en el melodrama tiende al derroche." ${ }^{133}$ La telenovela es parte de ese recorrido. Recibe estos esquemas y los moldea a su realidad y sus necesidades. Por eso no son ingenuos ni simplemente banales. Detrás suyo hay un contexto histórico y multiplicidad de sentidos producto de los antecedentes y condiciones socioculturales de una sociedad.

Nora y Ángel fueron los personajes protagónicos de las primeras dos telenovelas que se produjeron en México: Senda Probibida (1958) y Gutierritos (1958). Sus historias tenían que ver con personas comunes y corrientes

132 Martín-Barbero, Televisión y melodrama, pp. 39-45.

${ }^{133}$ Martín-Barbero, Televisión y melodrama, pp. 48-50. 
- en situaciones cotidianas y en espacios conocidos - , que se ven enfrentadas a circunstancias aparentemente extraordinarias. Una relación amorosa con un hombre casado, que además es su jefe, y una crisis matrimonial que recae en la actitud dominante de la esposa frente a su marido. Es el drama de la "casa chica", de la "rompehogares", seguido por la tragedia del hombre "apocado" por su mujer, de un "mandilón”. La “mala mujer” termina castigada socialmente, con una boda frustrada, sin la posibilidad de formar su propia familia nuclear. El hombre consigue un éxito efímero por el que es traicionado. Sin lograr la admiración de su esposa, finalmente enferma y muere. No son relatos con finales felices. Para la época, incluso, resultaban un tanto arriesgadas en su temática central. Lejos del estereotipo rosa que se ha construido alrededor de la telenovela, estas dos historias promovieron una narrativa más realista, sin perder el tono melodramático. Así, lograron conmover a un auditorio y abrir el camino al que será el producto televisivo de mayor relevancia en América Latina.

La conexión con los estereotipos y los significados más tradicionales y populares de la vida amorosa, la familia, la amistad o el ambiente laboral llevaron a la telenovela a insertarse con facilidad en la vida cotidiana de los televidentes. Aun novatos y extrañados, reconocieron en el melodrama no solo una fórmula de entretenimiento, sino de sentido. Quienes la acogieron como parte de sus rutinas se conmovieron con los personajes, siguieron las tramas y se reconocieron en la pantalla. Las telenovelas se vieron insertas en sus conversaciones, en sus comidas, en sus espacios de encuentro con la familia y amigos, en sus horarios y en sus espacios. Los habitantes de la ciudad de México de la década 
de 1950 se convirtieron entonces en televidentes. Su nueva condición los llevó a interactuar con el aparato telerreceptor, con el sistema televisivo y con programas como la telenovela, integrándolos a sus cotidianidades o creando nuevas. Ahora bien, esa interacción no era portadora de un ritmo único. La audiencia no era homogénea. Las telenovelas, como piezas de consumo y a la vez como producto cultural característico del siglo xx, se construyeron alrededor de la dialéctica televisión-televidente. En ese marco, no todos los espectadores iban a convertirse en asiduos seguidores, ni todos los melodramas iban a captar la atención de todos los televidentes. Pero seguramente, en la capital del país, tan viable era que hubiera espectadores "antitelenovela", como inviable que existieran individuos que no supieran siquiera de la existencia de este producto.

Las "Noras" y los "Gutierritos" se popularizaron incluso hasta saciar al espectador. Por eso abren un conjunto de preguntas por resolver. Registrar, desde una perspectiva histórica, la incursión de las primeras telenovelas en la vida cotidiana del público exige dejar capítulos pendientes para nuevas investigaciones. Quizá cuatro sean las posibles temáticas de dichas preguntas. Primero, la vida cotidiana que presentan las telenovelas. Esto implicaría ver en su contenido narrativo y dramático los tiempos, horarios, costumbres y rutinas de los personajes. ¿Qué tipo de vida cotidiana reflejan y qué tan lejano o cercano es a las realidades de los televidentes? Segundo, la vida cotidiana y las telenovelas en relación con las emociones y los sentimientos: aquellos que representan el contenido de la historia y aquellos que se despiertan entre los espectadores. Tercero, la creación de estereotipos e imágenes, que reflejen la forma como, en 
un tiempo y un lugar concretos, fue percibida la sociedad, sus preocupaciones y sus prioridades. Y cuarto, la telenovela como posible modelo y retrato de la cultura material de un contexto, situación socioeconómica o espacio: la moda, la comida, la tecnología, el mobiliario, la estética. Finalmente, cabe destacar que la telenovela refleja una forma particular de ver un contexto histórico, recrea creencias, iconos, fiestas, tradiciones, costumbres y conmemoraciones que dan cuenta de estereotipos y de realidades. Es el caso de figuras como la madre, la Virgen de Guadalupe, el "macho", el jefe, el "hijo rebelde", y hechos como el nacionalismo, el folclor, lo popular, el lenguaje, entre otros elementos que nos permiten dirigir la mirada a la formación de una cultura popular y a la cultura de masas.

Por último, la telenovela es un producto cultural hecho para significar. Sin una introducción a la vida cotidiana los significados que genera se disuelven. Es la evidencia de cómo una tecnología y una experiencia se integran a un día a día y crean nuevas cotidianidades hasta cobrar espacios, tiempos, prácticas y sentidos en una sociedad.

\section{REFERENCIAS}

BARRIOS, Leoncio

Televisión, telenovelas y vida cotidiana en el contexto de la familia, Caracas, Monte Ávila Editores, 1990.

Bauche Alcalde, Manuel

"Del teleteatro a la telenovela", en Apuntes para una historia de la televisión mexicana, México, Revista Mexicana de Comunicación, 1999, vol. II. 
Brown, Mary Ellen

Soap Opera and Women's Talk The Pleasure of Resistance, California, Sage Publications, 1994.

Carrandi Ortiz, Gabino

Testimonio de la televisión mexicana, México, Diana, 1986.

Castellot, Gonzalo

La televisión en México: 1950-2000, México, Edamex, 1999.

Castellot de Ballin, Laura

Historia de la televisión en México narrada por sus protagonistas, México, Alpe, 1993.

Covarrubias, Karla Y., Ana B. Uribe y Angélica Bautista

Cuéntame en qué se quedó. La telenovela como fenómeno social, México, Trillas y Felafacs, 1994.

Cueva, Álvaro

Lágrimas de cocodrilo, México, Tres Lunas, 1998.

De Certeau, Michel

La invención de lo cotidiano, México, Universidad Iberoamericana, 2007.

Encuesta

Encuesta nacional sobre radio y televisión, México, Universidad Nacional Autónoma de México, 1971.

Fernández, Juan A.

“'Fallas de origen'. Historia del encuentro entre la sociedad y la televisión mexicanas", tesis de licenciatura en historia, México, Universidad Nacional Autónoma de México, 2010.

GonZÁlez, Jorge A. (comp.)

La cofradia de las emociones (in)terminables: miradas sobre telenovelas en México, Guadalajara, Jal., Universidad de Guadalajara, 1998. 
GonzÁlez, Reynaldo

"Lágrimas de celuloide. Una nueva lectura para el melodrama cinematográfico latinoamericano", en Cine Latinoamericano años 30-40-50, México, Dirección General de Actividades Cinematográficas, Universidad Nacional Autónoma de México, 1990, pp. 143-148.

INEGI

Anuario estadístico 1958-1959, México, Instituto Nacional de Geografía y Estadística, 2009.

Lizaur, María Blanca

"La telenovela mexicana 1958-2002 - forma y contenido de un formato narrativo de ficción de alcance mayoritario", tesis de maestría en letras mexicanas, México, Universidad Nacional Autónoma de México, 2002.

Loakza, Soledad

"Modernización autoritaria a la sombra de la superpotencia, 1944-1968”, en Nueva historia general de México, México, El Colegio de México, 2010, pp. 653-698.

Luhman, Niklas

La realidad de los medios de masas, Madrid, Anthropos, 2000.

Martín-Barbero, Jesús

"La telenovela en Colombia: televisión, melodrama y vida cotidiana”, en Diálogos de la comunicación, 17, Lima, 1987 [http://www.essex.ac.uk/lang/spanish/Modules/La467/week16to20/LA467-TelenovColmb.pdf, consultado el 15 de octubre de 2013].

Martín-Barbero, Jesús, et al.

Televisión y melodrama. Géneros y lecturas de la televisión en Colombia, Bogotá, Tercer Mundo, 1992. 
Matute, Álvaro

"De la tecnología al orden doméstico en el México de la posguerra”, en ReYes (coord.), 2006, t. 5, pp. 157-176.

Mazziotti, Norma

Telenovela: industria y prácticas sociales, Bogotá, Grupo Norma, 2006.

Mejía Barquerera, Fernando

“Del canal 4 a Televisa”, en SÁnchez (coord.), 1998.

Monsiváis, Carlos

"Lo entretenido y lo aburrido. La televisión y las tablas de la ley", en Carlos Monsivárs, Aires de familia. Cultura y sociedad en América Latina, Barcelona, Anagrama, 2000.

Novo, Salvador

Memorias mexicanas. La vida en México en el periodo presidencial de Miguel Alemán, México, Conaculta, Instituto Nacional de Antropología e Historia, 1994.

Ornelas, Roberto

“Radio y cotidianidad en México (1900-1930)", en Reyes (coord.), 2006, t. 5, pp. 127-169.

Oroz, Silvia

Melodrama: el cine de lágrimas de América Latina, México, Universidad Nacional Autónoma de México, 1995.

Orozco, Guillermo

Historia de la televisión en América Latina, Barcelona, Gedisa, 2002.

Pérez Rubio, Pablo

El cine melodramático, Barcelona, Paidós Ibérica, 2004. 
Pierre, Albert, y Andre-Jean Tudesq

Historia de la radio y la televisión, México, Fondo de Cultura Económica, 1983.

Reyes, Aurelio de los

"Crimen y castigo. Las disfunción social en el México postrevolucionario", en Reyes (coord.), 2006, t. 5, pp. 301-343.

Reyes, Aurelio de los (coord.)

Historia de la vida cotidiana en México: siglo XX, la imagen, ¿espejo de la vida?, México, Fondo de Cultura Económica, El Colegio de México, 2006.

Reyes de la Maza, Luis

México sentimental. Crónica de la telenovela, México, Clío, 1999.

Rodríguez Kuri, Ariel y Renato González Mello

“El fracaso del éxito, 1970-1985”, en Nueva historia general de México, México, El Colegio de México, 2006, pp. 699-746.

Roura, Assumpta

Telenovelas, pasiones de mujer. El sexo del culebrón, Barcelona, Gedisa Editorial, 1993.

SÁnchez, Miguel (coord.)

Apuntes para una historia de la televisión mexicana, México, Televisa-RHM Comunicaciones, 1998.

Tuñón, Julia

Mujeres de luz y sombra en el cine mexicano. La construcción de una imagen (1939-1952), México, El Colegio de México, Instituto Nacional de Cinematografía, 1998. 
Entrevistas realizadas por la autora:

Entrevista Norma Inés Bolívar. Lugar de residencia décadas 1950-1960: México D. F. Lugar de entrevista: México D. F., casa de la entrevistada. Fecha: 10 de noviembre de 2012.

Entrevista Rosa María Tapia. Lugar de residencia décadas 1950-1960: México D. F. Lugar de entrevista: México D. F., Restaurante-Café Azul y Oro. Fecha: 15 de noviembre de 2012.

Entrevista Esperanza Calzada Mellado. Lugar de residencia décadas 1950-1960: México D. F. Lugar de entrevista: México D. F., casa de la entrevistada. Fecha: $1^{\circ}$ de noviembre de 2012. Entrevista Herlinda Calzada Mellado. Lugar de residencia décadas 1950-1960: México D. F. Lugar de entrevista: México D. F., casa de la entrevistada. Fecha: 1ํㅡoviembre de 2012. Entrevista Jairo Rodríguez Fuentes. Lugar de residencia décadas 1950-1960: México D.F. Lugar de entrevista: México D. F., casa del entrevistado. Fecha: 12 de noviembre de 2012. 